\title{
PENGARUH KUALITAS MANAJER PAJAK TERHADAP PENGHINDARAN PAJAK DENGAN ETIKA MACHIAVELLIAN SEBAGAI PEMEDIASI
}

\author{
Estralita Trisnawati, Roy Sembel, Juniati Gunawan, Waluyo \\ Universitas Tarumanagara, IPMI International Business School, Universitas Trisakti, \\ Universitas Mercubuana. \\ Email: Estris777@gmail.com
}

\begin{abstract}
This study aims to examine the effect of tax managers' quality on tax avoidance of manufacturing industry firms listed on the Indonesia Stock Exchange with machiavellian ethics as intervening. Using path analysis model with WarpPLS 5.0. This study examined the primary data for tax manager qualities and machiavellian ethics obtained from 103 tax managers working in manufacturing industry firms at IDX and secondary data from financial statements for tax avoidance. There are 10 tax avoidance indicators used as a proxy. This study gives results that the quality of tax managers have a significant positive effect on Machiavellian ethics. However, machiavellian ethics can not mediate the influence of tax manager quality on tax avoidance.
\end{abstract}

Keywords: the quality of tax managers, machiavellian ethics, tax avoidance, path analysis

\begin{abstract}
Abstraksi: Penelitian ini bertujuan menguji pengaruh kualitas manajer pajak terhadap penghindaran pajak perusahaan industri manufaktur yang terdaftar di Bursa Efek Indonesia dengan etika machiavellian sebagai pemediasi. Menggunakan model analisis jalur dengan WarpPLS 5.0. Penelitian ini menguji data primer untuk kualitas manajer pajak dan etika machiavellian yang diperoleh dari 103 manajer pajak yang bekerja di perusahaan industri manufaktur di BEI dan data sekunder dari laporan keuangan untuk penghindaran pajak. Ada 10 indikator penghindaran pajak yang digunakan sebagai proksinya. Penelitian ini memberikan hasil bahwa kualitas manajer pajak berpengaruh positif signifikan terhadap etika Machiavellian. Namun, etika machiavellian tidak dapat memediasi pengaruh kualitas manajer pajak terhadap penghindaran pajak.
\end{abstract}

Kata kunci: kualitas manajer pajak, etika machiavellian, penghindaran pajak, analisis jalur

\section{PENDAHULUAN}

Penelitian ini bertujuan untuk mendapatkan bukti empiris di Indonesia mengenai pengaruh kualitas manajer pajak terhadap penghindaran pajak dengan etika Machiavellian sebagai pemediasi. Penelitian ini dimotivasi dengan terkuaknya skandal Panama Papers dan semakin meningkatnya jumlah berkas perkara sengketa pajak yang terdaftar di pengadilan pajak, yaitu.

Tabel 1. Berkas perkara di Pengadilan Pajak tahun 2005 - 2015

\begin{tabular}{llllllllllll}
\hline tahun & 2005 & 2006 & 2007 & 2008 & 2009 & 2010 & 2011 & 2012 & 2013 & 2014 & 2015 \\
\hline $\begin{array}{l}\text { berkas } \\
\text { perkara }\end{array}$ & 4.821 & 5.162 & 7.594 & 10.781 & 14.473 & 16.522 & 16.534 & 16.068 & 16.341 & 17.914 & 18.402 \\
\hline
\end{tabular}

Sumber: www.setpp.depkeu.go.id 
Berkas perkara di pengadilan pajak ini terjadi karena perbedaan kepentingan dan persepsi dalam interpretasi dari kedua pihak yaitu otoritas pajak dengan Wajib Pajak (WP). Hal ini disebabkan karena pajak sebagai suatu pemindahan sumber daya dari perusahaan kepada negara. Pemindahan sumber daya ini akan mempengaruhi tujuan perusahaan untuk memaksimalkan laba melalui eksistensi dan likuiditas sehingga secara langsung maupun tidak langsung keputusan bisnis perusahaan dipengaruhi oleh kebijakan perpajakan yang dikeluarkan oleh Pemerintah (Suandy, 2011) dimana pajak merupakan beban bagi masyarakat WP. Sedangkan bagi otoritas pajak, pajak merupakan penerimaan Negara yang digunakan untuk pembangunan bagi kesejahteraan masyarakat sehingga penghindaran pajak masih memiliki arti konotasi negatif yang menyebabkan jumlah penerimaan negara menjadi berkurang (Suandy, 2011; Budiman dan Setiono, 2012). Penghindaran pajak juga dianggap kurang memiliki sifat sosial (Lanis \& Richardson, 2011) sehingga lebih cenderung memiliki pandangan etika Machiavellian (Shafer \& Simmons, 2008).

Namun, bagi WP yang rasional akan berusaha atau cenderung untuk meminimalkan beban pajaknya. Berbagai cara penghindaran pajak digunakan sebagai kegiatan yang legal dan tidak bertentangan dengan ketentuan perpajakan, seperti kasus Asian Agri ini diawali dari adanya upaya untuk melakukan penghindaran pajak, namun penghindaran pajak diduga bertentangan dengan peraturan perpajakan sehingga menimbulkan indikasi penggelapan pajak. Hasil putusan pengadilan memutuskan bahwa kasus ini termasuk kategori kasus penggelapan pajak karena adanya unsur pidana perpajakan dengan merugikan negara sebesar Rp 1,25 triliun yang dikutip dari merdeka.com.

Kasus-kasus penghindaran pajak ini merupakan salah satu faktor penyebab realisasi penerimaan perpajakan yang secara rata-rata tidak mencapai target seperti disajikan dibawah ini.

Tabel 2. Realisasi dan Target Penerimaan Pajak tahun 2005 - 2016

\begin{tabular}{llll}
\hline Tahun & $\begin{array}{l}\text { Realisasi } \\
(\text { Rp Trilyun })\end{array}$ & $\begin{array}{l}\text { Target Penerimaan } \\
(\text { Rp Trilyun) }\end{array}$ & $\begin{array}{l}\text { Pencapaian } \\
(\%)\end{array}$ \\
\hline 2005 & 346,8 & 297,8 & 116,50 \\
2006 & 409,2 & 425,1 & 96,30 \\
2007 & 491,0 & 492,0 & 99,80 \\
2008 & 633,8 & 609,2 & 104,00 \\
2009 & 641,3 & 651,9 & 98,40 \\
2010 & 723,3 & 743,3 & 97,30 \\
2011 & 873,7 & 878,7 & 99,40 \\
2012 & $1.011,70$ & $1.032,60$ & 98,00 \\
2013 & $1.072,10$ & $1.148,40$ & 93,40 \\
2014 & $1.143,30$ & $1.246,10$ & 91,80 \\
2015 & $1.055,00$ & $1.294,25$ & 81,50 \\
2016 & $1.504,50$ & $1.761,60$ & 85,40 \\
\hline
\end{tabular}

Sumber: www.kemenkeu.go.id

Ketidak tercapaian realisasi target penerimaan perpajakan ini telah disampaikan Dirjen Pajak saat bertemu dengan presiden (Kompas, 2014).

Aspek perpajakan merupakan faktor yang sangat dipertimbangkan perusahaan karena pajak merupakan beban yang signifikan dalam perusahaan. Sesuai tujuan 
perusahaan untuk mengoptimalkan laba, maka perusahaan berusaha meminimalkan beban pajaknya dengan memanfaatkan ketentuan perpajakan yang ada. Perusahaan akan melakukan penghindaran pajak untuk mengurangi beban pajak yang muncul (Chen, et al; 2010). Oleh karena itu, suatu perusahaan memerlukan adanya strategi mengatur jumlah pajak yang akan dibayarnya dengan baik, atau dapat dikatakan bahwa perusahaan perlu adanya strategi manajemen pajak. Menurut Hoffman (1961) perencanaan pajak dilakukan oleh pihak perusahaan yang dilakukan oleh manajer pajak atau dapat pula dibantu oleh konsultan pajak.

Manajer pajak ataupun konsultan pajak sering disebut sebagai profesional pajak yang dapat melakukan perencanaan pajak dengan teknik penghindaran (Hoffman, 1961). Manajer pajak sebagai profesional pajak internal perusahaan yang memiliki kompetensi dibidang perpajakan dan komitmen pada keputusan yang telah ditetapkan oleh manajemen puncak. (Zuber, 2007; Waegenaere, Sansing \& Wielhouwer, 2013). Penelitian mengenai peran manajer pajak terhadap penghindaran pajak kebanyakan diukur dengan menggunakan kompensasi insentif (Desai \& Dharmapala, 2004/2006; Chen \& Chu, 2005; Shafer \& Simmons, 2008; Rego \& Wilson, 2009; Crocker \& Slemrod, 2005; Amstrong, et al. 2011; Gaertner, 2011, Graham, et al. 2011; Jalan, et al. 2013). Penelitian Amstrong, et al (2011) membuktikan bahwa insentif yang diberikan kepada manajer pajak mengindikasikan berkurangnya beban pajak yang dilaporkan dalam laporan keuangan. Namun, hasil penelitian ini bertolak belakang dengan hasil penelitian Desai dan Dharmapala (2004/2006) yang mengatakan bahwa peningkatan kompensasi insentif cenderung mengurangi tingkat tax sheltering. Karena masih adanya perbedaan-perbedaan hasil penelitian tersebut maka penelitian ini diharapkan dapat memberikan kontribusi. Dalam penelitian ini peran manajer pajak diukur menggunakan kompetensi yang dimiliki oleh manajer pajak dalam melakukan penghindaran pajak yang merupakan salah satu tindakan etika Machiavellian dan komitmennya pada keputusan yang telah ditetapkan oleh manajemen puncak.

Masalah etika dalam pembayaran pajak telah dibahas dalam literatur teologis dan filsafat setidaknya 500 tahun. Selama berabad-abad, tiga pandangan utama berevolusi pada topik etika dalam perpajakan tersebut. Masalah etika ini dikemukakan oleh McGee dan Cohn (2008), yang dimulai dengan tinjauan literatur dan mengidentifikasi isu-isu utama serta merangkum tiga sudut pandang utama yang muncul selama berabad-abad; kemudian laporan tentang hasil dua survei dari anggota kepercayaan Yahudi yang ditanya pendapatnya tentang etika penggelapan pajak. Penelitian mengenai etika telah dilakukan selama bertahun-tahun, namun masalah yang tetap belum terpecahkan, yaitu pengambilan keputusan yang etis. Penelitian McGee dan Cohn ini didukung dari hasil penelitian Palau (2006) yang memberikan bukti kuat adanya hubungan antara budaya dan etika dalam pengambilan keputusan. Dalam penelitiannya Palau menggunakan Multidimensional Ethics Scale (MES) untuk menjelaskan evaluasi etika, penilaian dan niat responden dalam konteks lintas budaya. Lemon (1996) dalam Crossman (2008) juga percaya bahwa akuntan profesional diharapkan harus memiliki etika sehingga dapat diminta untuk menangani isuisu etis yang sulit dalam pengambilan keputusan. Penelitian Feng (2008) berhasil membuktikan bahwa persepsi profesional akuntansi masih memiliki standar etika yang rendah dan oleh karena itu kredibilitasnya terbukti berkurang dengan banyak skandal global selama sepuluh tahun terakhir termasuk Enron, WorldCom, Merck dan Xerox. 
Dengan demikian, mengembangkan pemahaman perkembangan moral akuntan profesional dan faktor-faktor yang mempengaruhi keputusan etis menjadi sangatlah penting.

Artikel jurnal Alm dan Togler (2011) mengatakan bahwa teka-teki kepatuhan pajak dapat dijelaskan, setidaknya sebagian, dengan mengakui peran etika yang biasanya diabaikan dalam perilaku individu; yaitu, individu tidak selalu berperilaku sebagai egois, rasional, individu mementingkan diri sendiri digambarkan dalam standar paradigma neoklasik, melainkan sering termotivasi oleh banyak faktor lain yang memiliki beberapa aspek "etika" sebagai pondasi utamanya. Dalam penelitian Alm dan Togler dikemukakan bahwa tidak mungkin untuk memahami sepenuhnya keputusan kepatuhan individu tanpa mempertimbangkan dalam beberapa bentuk dimensi etika. Secara khusus, penelitian Alm dan Togler mendapatkan bukti bahwa etika berbeda pada seluruh individu dan perbedaan ini penting pada cara pengambilan keputusan yang signifikan untuk kepatuhan para individu tersebut.

Berdasarkan latar belakang penelitian tersebut maka penelitian ini ingin melihat pengaruh langsung maupun tidak langsung kualitas manajer pajak terhadap penghindaran pajak melalui etika machiavellian. Sedangkan tujuan dilakukannya penelitian ini adalah untuk memberikan bukti secara empiris bahwa kualitas manajer pajak memiliki pengaruh langsung maupun tidak langsung terhadap penghindaran melalui etika machiavellian. Penelitian ini juga diharapkan bermanfaat untuk menambah pengetahuan dan wawasan mengenai kualitas manajer pajak, etika Machiavellian dan penghindaran pajak sehingga dapat memberikan sumbangan pemikiran dan referensi untuk penelitian selanjutnya juga dapat memberikan masukan pada Pemerintah khususnya Direktorat Jenderal Pajak untuk meningkatkan pendapatan Negara melalui sektor perpajakan.

\section{KAJIAN TEORI}

Teori Keperilakuan. Penelitian ini menggunakan teori keperilakuan dalam akuntansi keperilakuan karena laporan keuangan yang dilampirkan dalam pelaporan Surat Pemberitahuan Pajak (SPT) badan melibatkan ringkasan dari sejumlah kejadian ekonomi yang dihasilkan dari perilaku pihak manajemen yang bersama-sama dalam menentukan kinerjanya. Jadi, informasi pada laporan keuangan itu berkaitan dengan perilaku manajemen dalam penelitian ini manajer pajak sebagai manusia yang ternyata mempengaruhi data akuntansi berupa laporan keuangan yang digunakan sebagai dasar pengenaan pajak.

Berdasarkan uraian diatas, maka penelitian ini menggunakan teori kontemporer motivasi, berupa teori atribusi seperti dibawah ini.

Teori Atribusi. Teori atribusi dikembangkan oleh Fritz Heider (1958) yang berpendapat bahwa perilaku seseorang ditentukan oleh kombinasi antara internal forces, yaitu faktorfaktor yang berasal dari dalam diri seseorang, seperti kemampuan atau usaha, dan eksternal forces, yaitu faktor-faktor yang berasal dari luar seperti kesulitan dalam pekerjaan atau keberuntungan (Lubis, 2010). Pada dasarnya teori ini menyarankan bahwa jika ingin mengamati perilaku seorang maka perilaku orang tersebut akan ditentukan oleh faktor internal dan eksternal. Perilaku yang disebabkan oleh faktor internal adalah perilaku yang diyakini berada dibawah kendali pribadi individu itu sendiri, sedangkan perilaku yang disebabkan oleh faktor eksternal adalah perilaku yang dipengaruhi dari luar, yaitu perilaku seseorang dilihat sebagai akibat dari tekanan situasi atau lingkungannya. 
Penentuan faktor internal atau eksternal menurut Lubis (2010) tergantung pada tiga faktor yaitu.

a) Perbedaan (distinctiveness), artinya seseorang akan mempersepsikan perilaku individu lain secara berbeda-beda dalam situasi yang berlainan. Apabila perilaku seseorang dianggap suatu hal yang tidak biasa maka individu lain yang bertindak sebagai pengamat akan memberikan atribusi eksternal terhadap perilaku tersebut. Sebaliknya jika hal itu dianggap hal yang biasa maka akan dinilai sebagai atribusi internal.

b) Konsensus (consensus), artinya semua orang mempunyai kesamaan pandangan dalam merespon perilaku seseorang jika dalam situasi yang sama. Apabila konsensusnya tinggi maka termasuk atribusi eksternal. Sebaliknya jika konsensusnya rendah maka termasuk atribusi internal.

c) Konsistensi (consistency), artinya seseorang menilai perilaku-perilaku orang lain dengan respon yang sama dari waktu ke waktu. Semakin konsisten perilaku itu maka orang akan menghubungkan hal tersebut dengan sebab-sebab internal, dan sebaliknya.

Dalam penelitian ini, teori atribusi berhubungan dengan sikap manajer pajak dalam membuat penilaian terhadap pengertian pajak itu sendiri yang merupakan faktor internal dari seseorang, sedangkan kontrak antara pemilik dengan manajemen (insentif/bonus), iklim etis di perusahaan dan sosialisasi kode etik profesi merupakan faktor eksternal yang akan mempengaruhi seseorang dalam mengambil keputusan.

Teori perkembangan moral. Teori perkembangan moral Lawrence Kohlberg merupakan pengembangan teori struktural kognitif yang telah dilakukan Jean Piaget (1896-1980) sebelumnya. Di atas bangunan teori Piaget itu, Kohlberg mengusulkan suatu teori perkembangan penalaran moral (teori development-kognitif) dimana menurutnya perkembangan moral seseorang didasarkan terutama pada penalaran moral yang akan berkembang secara bertahap.

Penalaran moral dapat diartikan sebagai suatu proses pemikiran seseorang mengenai dilema etis, yang kemudian sampai pada pengambilan keputusan bahwa sesuatu itu baik atau buruk. Tahapan perkembangan moral adalah ukuran dari tinggi rendahnya moral seseorang berdasarkan perkembangan penalaran moralnya seperti yang diungkapkan oleh Kohlberg yang dikenal dengan teori perkembangan moral kognitif. Perkembangan penalaran moral ini, merupakan faktor penentu yang menghasilkan keputusan yang etis sehingga untuk menemukan perilaku moral yang sebenarnya hanya dapat ditelusuri melalui penalarannya. Artinya, pengukuran moral yang benar tidak sekedar mengamati perilaku moral yang tampak saja, tetapi harus melihat pada kesadaran moral yang mendasari pengambilan keputusan etis tersebut. Dengan diketahui tinggi rendahnya penalaran moral tersebut maka tingkat perkembangan moralnya akan dapat diukur. Dalam penelitian ini, manajemen puncak dihadapkan pada pilihan untuk melakukan penghindaran pajak secara agresif atau tidak dimana keputusan yang diambil tersebut dapat menimbulkan terjadinya risiko diperiksa oleh otoritas pajak atau tidak. Apabila keputusan penghindaran pajak secara agresif yang diambil oleh manajemen puncak tersebut maka untuk mengetahui keputusan yang telah diambil tersebut termasuk dalam keputusan yang etis atau kurang etis, haruslah ditelusuri penalarannya sehingga dapat ditemukan perilaku moral yang sebenarnya.

Teori perkembangan moral Kohlberg ini telah banyak digunakan dalam memahami alasan yang dibuat seseorang pada saat membuat keputusan etis. Kohlberg mendefinisikan 
penalaran moral sebagai pertimbangan mengenai benar dan salah, sedangkan perkembangan moral adalah tahap kematangan penalaran moral. Dia juga mendefinisikan tahap penalaran moral sebagai penalaran yang digunakan untuk mempertahankan moral ketika dihadapkan pada dilema moral. Teori perkembangan moral mengatakan penalaran etis kognitif merupakan hal yang sangat kompleks sebagai proses peningkatan dan kematangan kognitif. Apabila dikaitkan dengan kerelaan membayar pajak maka keputusan penghindaran pajak ini, walaupun tidak melanggar hukum tetapi dapatlah dikatakan sebagai suatu keputusan yang diharapkan memerlukan kematangan dalam penalaran etisnya.

Paham machiavellian diajarkan oleh seorang ahli filsuf politik dari Italia yang bernama Niccolo Machiavelli (1469-1527). Machiavellian didefinisikan sebagai sebuah proses dimana manipulator mendapatkan lebih banyak reward dibandingkan yang dia peroleh ketika tidak melakukan manipulasi. Sifat machiavellian diekspektasikan menjadi konstruk tambahan yang mempengaruhi seseorang untuk berperilaku tidak etis atau membantu menstimulus perbedaan perilaku etis. Individu dengan sifat machiavellian yang tinggi cenderung lebih berbohong, kurang bermoral, dan lebih manipulatif (Christie \& Geis, 1970 dalam Shafer \& Simmons, 2008).

Kepribadian machiavellian ini dideskripsikan sebagai kepribadian yang kurang mempunyai afeksi dalam hubungan personal, mengabaikan moralitas konvensional dan memperlihatkan komitmen ideologi yang rendah sehingga mempunyai kecenderungan untuk memanipulasi orang lain (Christie \& Geis, 1970 dalam Shafer \& Simmons, 2008). Kohlberg (1981) menjelaskan bahwa orientasi etika mempunyai hubungan dengan dimensi-dimensi etis seperti paham machiavellian sehingga skala machiavellian ini menjadi proksi perilaku moral yang mempengaruhi perilaku dalam pembuatan keputusan yang etis (Hegarty \& Sims,1978 dan 1979 dan Trevino et al. 1985 dalam Purnamasari \& Chrismastuti, 2006) maka dapat diekspektasikan bahwa individu dengan sifat machiavellian yang tinggi akan lebih mungkin melakukan tindakan yang tidak etis dibandingkan individu dengan sifat machiavellian yang rendah.

Semakin baik perkembangan moral seseorang maka orang tersebut akan semakin dapat berperilaku etis dengan memiliki sifat machiavellian yang rendah. Namun, teori Kohlberg menerangkan perkembangan moral individu tidak sejalan dengan bertambahnya usia sehingga hasil dari perkembangan moral ini tidak menunjukkan tindakan yang etis, seperti tindakan para pengemplang pajak dan koruptor. Mereka memiliki sifat machiavellian yang tinggi dengan tingkat perkembangan moral rendah yang tidak diikuti dengan bertambahnya usia.

Pengaruh Kualitas Manajer Pajak terhadap Penghindaran Pajak. Penelitian yang dilakukan oleh Chen dan Chu (2005) menyatakan bahwa jika perusahaan ingin melakukan penghindaran pajak maka perusahaan harus memberikan kompensasi yang optimal pada manajer. Hal yang sama juga dinyatakan oleh Crocker dan Slemord (2005) bahwa semakin rendah tingkat pajak yang ingin dibayarkan maka akan semakin tinggi jumlah insentif yang harus diberikan. Kompensasi dan insentif tersebut dapat menjadi motivasi manajer yang dapat mempengaruhi komitmen dari manajer itu sendiri dimana jika manajer ingin mendapatkan insenif yang tinggi maka mereka akan bersedia melakukan penghindaran pajak.

Desai dan Dharmapala (2005) dalam penelitiannya mengatakan bahwa peningkatan kompensasi insentif cenderung mengurangi tingkat tax sheltering. Hal ini sejalan dengan 
hasil penelitian Desai dan Dharmapala (2004/2006) yang menunjukkan bahwa insentif manajer berpengaruh signifikan terhadap penghindaran pajak, dimana manajer dengan insentif yang tinggi cenderung lebih sedikit melakukan penghindaran pajak. Temuan mereka menunjukkan bahwa pandangan sederhana penghindaran pajak perusahaan sebagai transfer sumber daya dari negara kepada pemegang saham tidaklah lengkap, mengingat masalah hubungan karakteristik agensi pemegang saham dengan manager.

Tetapi hasil penelitian Graham, et al (2011) dan Armstrong, et al (2014) menunjukkan bahwa insentif yang tinggi akan mendorong para manajer untuk melakukan penghindaran pajak. Armstrong, et al (2011) menggunakan rincian data eksklusif mengenai informasi kompensasi eksekutif untuk menguji hubungan antara insentif dari direktur pajak dan GAAP serta cash ETR, book-tax gap dan ukuran agresivitas pajak. Mereka menemukan bahwa kompensasi insentif dari direktur pajak menunjukkan hubungan negatif yang kuat dengan GAAP ETR, tetapi sedikit hubungannya dengan atribut pajak lainnya. Armstrong, et al juga menginterpretasikan hasil ini sebagai indikasi bahwa direktur pajak diberikan insentif untuk mengurangi tingkat beban pajak yang dilaporkan dalam laporan keuangan.

Penelitian yang dilakukan oleh Ross dan McGee (2012), dimana semakin rendah tingkat pendidikan maka semakin menentang penghindaran pajak. Apabila kompetensi yang dimiliki mampu mendukung seorang manajer memanfaatkan kelemahan sistem dan aturan perpajakan maka bisa saja manajer akan mengambil keputusan untuk melakukan penghindaran pajak.

Manajer pajak termasuk sebagai salah satu profesional pajak yang membantu dalam proses penghindaran pajak (Hoffman, 1961). Kualitas manajer pajak merupakan bentuk kompetensi yang dimiliki oleh manajer di bidang perpajakan dan komitmen pada kontrak perusahaan. Manajer pajak sebagai pelaksana dari keputusan penghindaran pajak yang ditetapkan oleh manajemen puncak, sesuai dengan kompetensi yang dimilikinya (Zuber, 2007; Waegenaere, et al. 2013) dengan memanfaatkan kesempatan dan lemahnya penegakan hukum serta aturan perpajakan (Hutagaol, 2007). Manajer pajak juga wajib patuh terhadap komitmen pada kontrak dengan mematuhi keputusan yang telah diputuskan oleh manajemen puncak sebagai wujud pendelegasian wewenang. Kompetensi yang dimiliki dan komitmen yang tinggi akan menyebabkan semakin tinggi kinerja yang ingin ditampilkan oleh manajer (Widodo, 2009) apalagi manajer pajak diberikan insentif untuk mengurangi beban pajak yang dibayar oleh perusahaan (Desai \& Dharmapala, 2004/2006; Chen \& Chu, 2005; Crocker \& Slemrod, 2005; Shafer \& Simmons, 2008; Rego \& Wilson, 2009; Amstrong, et al. 2011; Gaertner, 2011, Graham, et al. 2011; Jalan, et al. 2013). Hal ini terjadi pada kasus sengketa pajak yang ada di Pengadilan Pajak.

Dari uraian di atas dapat disimpulkan bahwa kompetensi yang dimiliki dan komitmen yang tinggi akan menyebabkan semakin tinggi kinerja yang ingin ditampilkan oleh manajer apalagi manajer pajak diberikan insentif untuk mengurangi beban pajak yang dibayar oleh perusahaan. Berdasarkan kesimpulan di atas, maka hipotesis yang diajukan adalah sebagai berikut:

H1: Kualitas manajer pajak berpengaruh positif terhadap penghindaran pajak.

Pengaruh tidak langsung Kualitas Manajer terhadap Penghindaran Pajak melalui Etika Machiavellian. Dunham dan Washer (2012) mengatakan bahwa eksekutif dari banyak perusahaan publik setuju untuk paket kompensasi yang menciptakan eksposur 
besar ke saham pemilik mereka. Dewan perusahaan memotivasi eksekutif untuk membuat keputusan nilai yang maksimal, dengan cara mengaitkan pendapatan seorang eksekutif terhadap kinerja harga saham melalui saham atau opsi. Namun, hal ini menimbulkan suatu dilema etis yang signifikan bagi banyak eksekutif yang tidak nyaman dengan risiko perusahaan yang cukup besar, dan keinginannya untuk menguranginya melalui kegiatan hedging. Penelitian baru-baru ini telah menunjukkan bahwa hedging eksekutif telah menjadi lebih umum. Pada intinya, apabila terjadi ekonomi yang akut maka manajer melepaskan insentif dan bertindak demi kepentingan pemilik. Ini tampaknya melanggar semangat kontrak kompensasi dan dari sudut pandang normatif, bagaimana eksekutif tidak harus bertindak. Pada artikel jurnal ini, Dunham dan Washer menjelaskan bagaimana beberapa eksekutif bertindak dalam masalah etika ini, bagaimana mereka harus bertindak dan bagaimana mereka dapat membantu untuk mendapatkan dari apa yang mereka lakukan, serta apa yang mereka harus melakukan.

Tujuan penelitian Tuan (2011) ke perusahaan yang terdaftar di Bursa Efek kota Ho Chi Minh (HOSE) di Vietnam adalah berusaha untuk melihat konstruksi tanggung jawab sosial perusahaan (CSR) dan etika bekerja sebagai pendahulu untuk tata kelola perusahaan. 317 tanggapan kembali dari kuesioner terstruktur yang disampaikan kepada 1.173 manajer tingkat menengah yang dianalisis melalui ANOVA dengan model persamaan struktural. Dari hasil penelitian Tuan adalah suatu interaksi yang muncul di antara etika keadilan dan legalitas CSR / ekonomi CSR. Etika perawatan, di sisi lain, cenderung menumbuhkan etika CSR, yang pada gilirannya mempengaruhi secara positif tata kelola perusahaan. Penelitian Tuan juga memberikan wawasan mengenai pola hubungan dari tata kelola dan pendahulunya yang menyoroti besarnya program pelatihan etika serta inisiatif CSR dalam memperkuat tata kelola pada perusahaan yang terdaftar di Vietnam.

Kualitas manajer pajak merupakan bentuk kompetensi yang dimiliki oleh manajer dan komitmen manajer pada perusahaan yang memfokuskan pada kegiatan yang mendukung keputusan manajemen puncak dimana kegiatan tersebut merupakan wujud pendelegasian dari manajemen puncak (Zuber, 2007; Waegenaere, et al. 2013). Manajer pajak sebagai profesional pajak yang memiliki kompetensi dibidang perpajakan (Hoffman, 1961) wajib mematuhi perintah dari manajemen puncak berdasarkan kontrak komitmennya pada perusahaan. Atas komitmennya maka manajer pajak akan diberikan peningkatan kompensasi insentif oleh manajemen puncak (Amstrong, et al. 2011) sehingga manajer pajak lebih memilih untuk mengabaikan nilai-nilai etika deontologi dengan mengorbankan kepentingan publik (He \& Ho, 2010; Stuebs \& Wilkinson, 2010; Alm \& Togler, 2011). Pengabaian nilai-nilai etika deontologi ini mengindikasikan masih rendahnya perkembangan moral manajer pajak (Kohlberg, 1981). Namun, sesuai dengan sifat machiavellian yang lebih mengutamakan keegoisannya (Shafer \& Simmons, 2008) maka teknik strategi penghindaran pajak dilakukan oleh manajer pajak dengan mengeluarkan kompetensi dan komitmennya pada keputusan pihak manajemen.

Dari uraian di atas dapat disimpulkan bahwa kualitas dan komitmen yang dimiliki oleh manajer pajak digunakan untuk mendukung keputusan manajemen puncak untuk melakukan penghematan pajak melalui strategi penghindaran pajak dengan mengabaikan kepentingan publik yang sejalan dengan paham machiavellian. Berdasarkan kesimpulan diatas, maka hipotesis yang diajukan adalah sebagai berikut: 
H2: Pengaruh tidak langsung kualitas manajer pajak terhadap penghindaran pajak melalui etika machiavellian.

\section{METODE}

Populasi dari penelitian ini terdiri dari dua yaitu pertama, untuk data primer populasinya sebanyak 140 orang yang terdiri dari manajer pajak perusahaan industri manufaktur yang terdaftar pada pada BEI. Kedua, untuk data sekunder populasinya adalah perusahaan industri manufaktur yang terdaftar di BEI sejak tahun 2010-2014 sebanyak 140 perusahaan.

Metode pengambilan sampel dalam penelitian ini adalah purposive dengan kriteria bahwa perusahaan tidak disuspen, didelisting atau relisting dan perusahaan tidak IPO selama periode tahun 2011 - 2014 sehingga perusahaan dapat menerbitkan laporan tahunan ke BEI selama periode tahun 2010 sampai dengan 2014 serta bukan perusahaan BUMN. Hal ini dikarenakan perusahaan BUMN cenderung tidak melakukan penghindaran pajak, sesuai dengan pernyataan Menteri Negara BUMN yang pada saat itu dijabat oleh Sofyan Djalil (tempo.co, 2009). Jumlah sampel yang digunakan dalam penelitian ini adalah 120 perusahaan.

Operasionalisasi variabel mendefinisikan mengenai variabel-variabel yang diteliti dalam penelitian ini dengan menjelaskan atau mengidentifikasikan indikator-indikator variabel yang diukur. Penjelasan mengenai konsep variabel dan indikator yang terlibat dapat dilihat pada tabel berikut.

Tabel 3. Operasionalisasi variabel

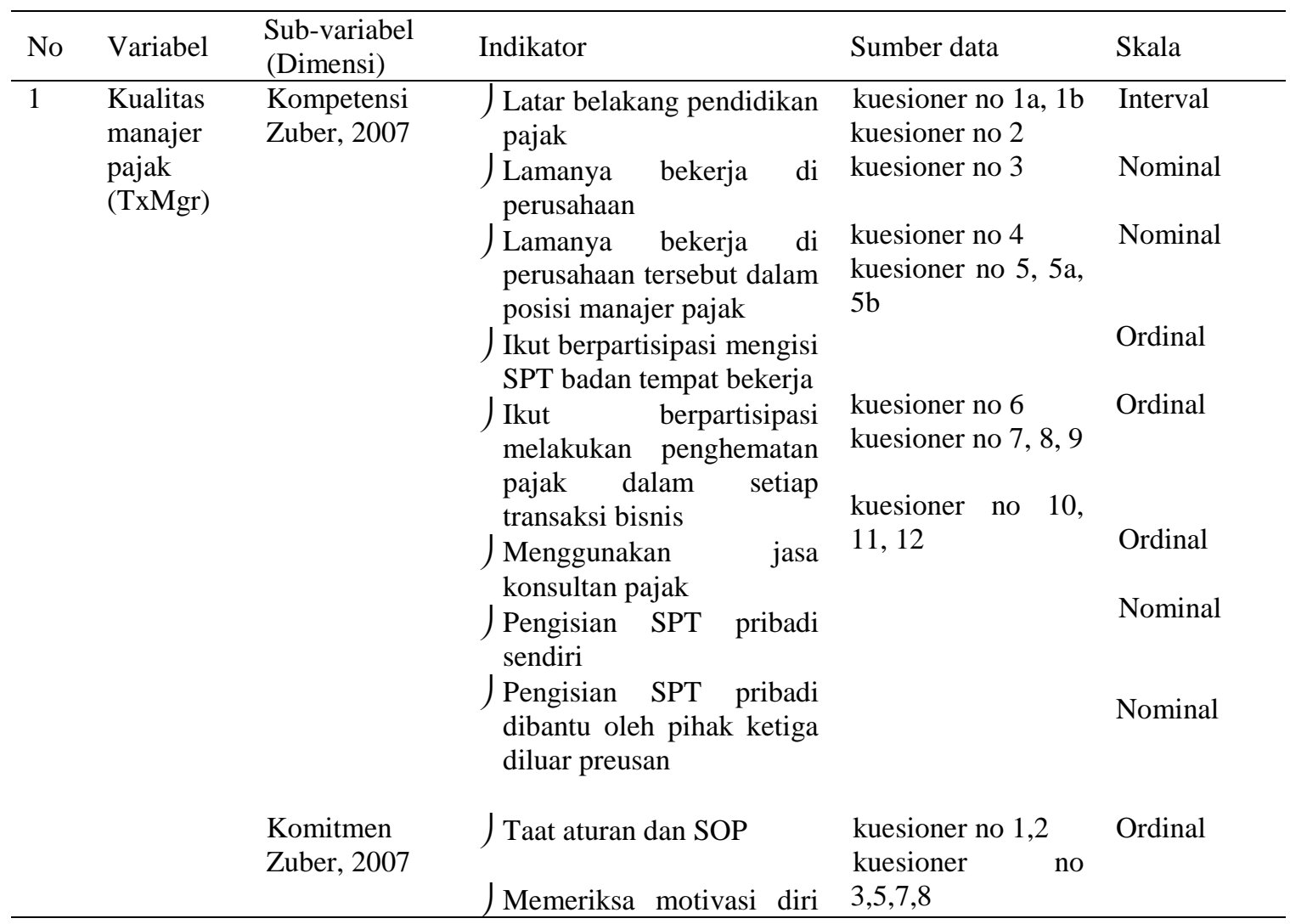




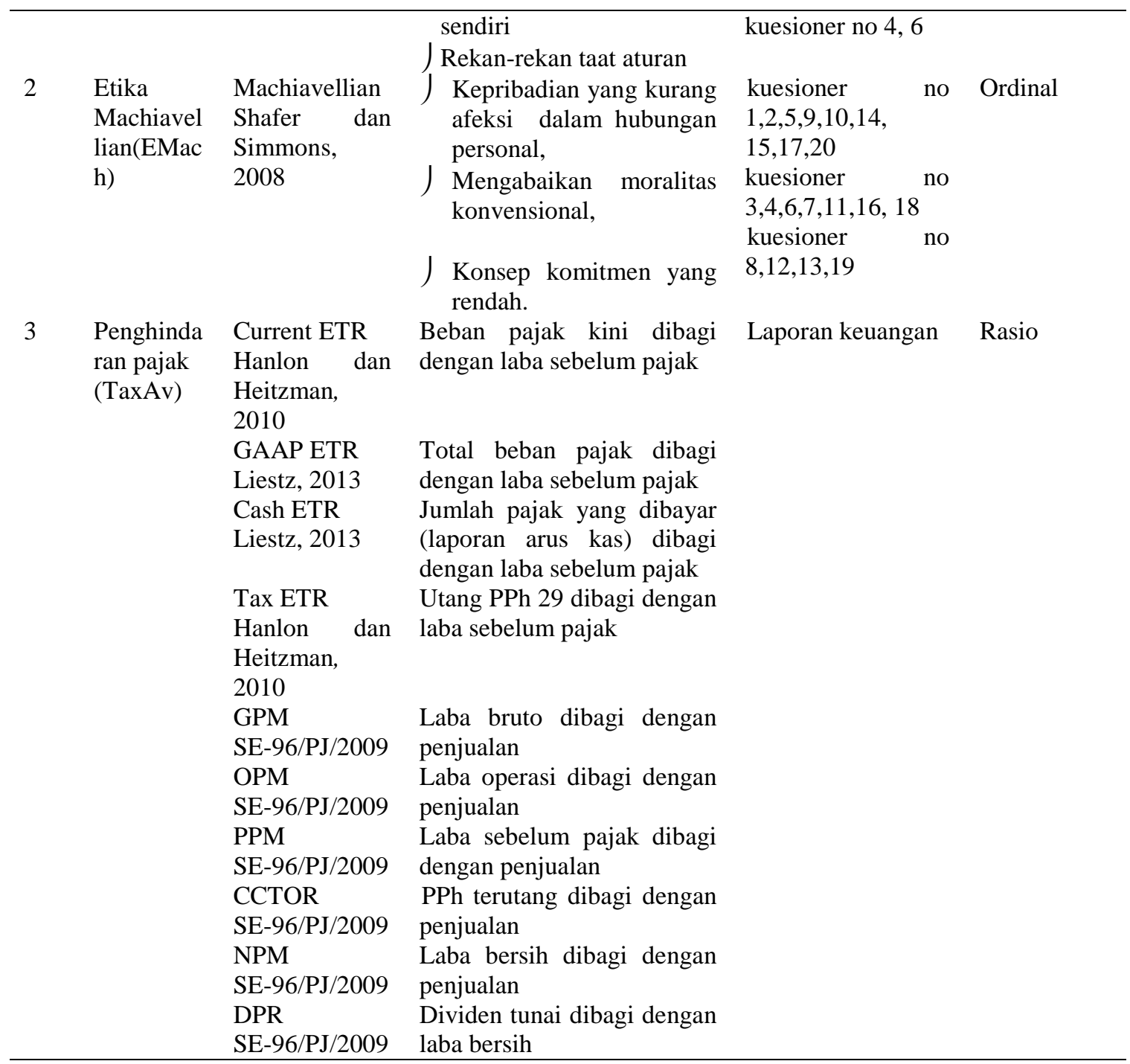

\section{Sumber: diolah sendiri}

Model yang dipakai dalam penelitian ini adalah sebagai berikut.

Persamaan 1 untuk menguji H1 yaitu

$\operatorname{TaxAv}_{\mathrm{i}}=\beta_{0}+\beta_{1} \mathrm{TxMgr}_{\mathrm{i}}+\beta_{2} \mathrm{dLK}_{\mathrm{i}}+\beta_{3} \mathrm{dSPT}_{\mathrm{i}}+\beta_{4} \mathrm{EMach}_{\mathrm{i}}+1 \mathrm{i}$

Persamaan 2 untuk menguji $\mathrm{H} 2$ yaitu

$\mathrm{EMach}_{i}=\beta_{0}+\beta_{1} \mathrm{TxMgr}_{\mathrm{i}}+\beta_{2} \mathrm{dLK}_{\mathrm{i}}+\beta_{3} \mathrm{dSPT}_{\mathrm{i}}+2 \mathrm{i}$

Data yang terkumpul akan diolah dan dianalisis dengan menggunakan program SPSS 20.00 dan WarpPLS 5.0.

\section{HASIL DAN PEMBAHASAN}

Total sampel dalam penelitian ini adalah perusahaan industri yang terdaftar di BEI sebanyak 140 perusahaan selama periode tahun 2010 - 2014. Namun, hanya 120 perusahaan yang dijadikan sampel dalam penelitian ini karena hanya 120 perusahaan yang sesuai dengan kriteria pengambilan sampel. 20 perusahaan dikeluarkan dari sampel karena 5 perusahaan merupakan perusahaan BUMN, 2 perusahaan tidak ada data laporan 
keuangan, 2 perusahaan yang melakukan delisting, 1 perusahaan melakukan relisting, 2 perusahaan disuspensi oleh BEI dan sisanya 8 perusahaan yang melakukan IPO pada periode 2010 - 2014. Kuesioner yang telah dikirimkan kepada responden adalah sebanyak 143 kuesioner kepada corporate secretary perusahaan tbk yang dijadikan sampel, kemudian diberikan manajer pajak pada bulan September hingga Desember 2015. Hasil pengembalian kuesioner oleh responden tersebut sebanyak 103 kuesioner oleh manajer pajak sehingga diperoleh respon rate sebesar $85,84 \%$.

Hasil Pengujian Validitas dan Reliabilitas. Hasil pengujian validitas menggunakan pearson correlation (sig. 2-tailed) untuk variabel kualitas manajer pajak seperti pada tabel dibawah ini.

Tabel 4. Hasil pengujian validitas variabel kualitas manajer pajak (x1)

\begin{tabular}{|c|c|c|c|}
\hline Instrumen & Kompetensi & & Komitmen \\
\hline 4 & 0.000 & & \\
\hline 5 & 0.000 & & \\
\hline $5 a$ & 0.000 & & \\
\hline $5 b$ & 0.000 & & \\
\hline 6 & 0.000 & & \\
\hline 8 & 0.000 & & \\
\hline 9 & 0.000 & & \\
\hline 11 & & 0.000 & \\
\hline 12 & & 0.001 & \\
\hline 1 & & & 0.000 \\
\hline 2 & & & 0.000 \\
\hline 3 & & & 0.000 \\
\hline 4 & & & 0.000 \\
\hline 5 & & & 0.000 \\
\hline 6 & & & 0.000 \\
\hline 7 & & & 0.000 \\
\hline 8 & & & 0.000 \\
\hline
\end{tabular}

Sumber: Data diolah SPSS 20.00

Keseluruhan instrumen dimensi kompetensi dan komitmen pada variabel kualitas manajer pajak sebesar 0.000 dan 0.001 yang lebih kecil dari 0.05 sehingga dapat disimpulkan bahwa instrumen pada variabel x1 telah valid dan dapat digunakan untuk penelitian.

Tabel 5 dibawah ini menunjukkan hasil pengujian reliabilitas karena nilai cronbach's alpha lebih besar dari standar minimum cronbach's alpha sebesar 0.600 sehingga dapat disimpulkan bahwa variabel kualitas manajer pajak telah reliabel dan dapat digunakan untuk penelitian.

Tabel 5. Hasil pengujian reliabilitas variabel kualitas manajer pajak (x1)

\begin{tabular}{lll}
\hline Keterangan & Jumlah responden & Reliabilitas \\
\hline Kompetensi A4 - A6 & 103 & 0.856 \\
Kompetensi A8 dan A9 & 90 & 0.926 \\
Kompetensi A11 dan A12 & 13 & 0.638 \\
Komitmen & 103 & 0.931 \\
\hline
\end{tabular}

Sumber: Data diolah SPSS 20.00 
Pengujian validitas dan reliabilitas untuk kuesioner variabel etika Machiavellian yang telah diisi sebanyak 103 kuesioner oleh manajer pajak. Hasil pengujian validitas untuk variabel etika machiavellian dengan menggunakan pearson correlation (sig. 2-tailed) masing-masing instrumen sebesar 0.000. Hasil pengujian reliabilitas variabel etika Machiavellian menggunakan nilai cronbach's alpha sebesar 0.724 yang lebih besar dari 0.600 sehingga dapat disimpulkan bahwa variabel etika Machiavellian telah valid dan reliabel.

Deskriptif Statistik Data Primer Manajer pajak dan Etika Machiavellian. Manajer pajak yang bekerja pada perusahaan industri manufaktur yang terdaftar di BEI adalah responden dalam penelitian ini. 120 kuesioner telah dikirimkan kepada corporate secretary perusahaan tbk untuk diberikan kepada manajer pajak. 103 kuesioner telah dikembalikan oleh responden sehingga diperoleh respon rate sebesar $85.84 \%$.

Tabel 6 dibawah dapat diketahui tingkat pendidikan formal yang dimiliki oleh manajer pajak adalah sebagian besar berpendidikan sarjana atau S1 sebanyak $71 \%$, berpendidikan magister atau S2 sejumlah $27 \%$ dan berpendidikan doktor atau S3 sebesar 2\%. Tingkat pendidikan perpajakan non formal (brevet dan USKP) yang dimiliki oleh manajer pajak maka sebagian besar telah lulus USKP sebanyak $87 \%$ dan yang tidak memiliki brevet dan USKP sebesar 13\%. Sebagian besar manajer pajak telah bekerja selama lebih dari 10 tahun sebanyak 40\%, bekerja selama 7-10 tahun sejumlah 19\%, sedangkan yang telah bekerja selama 4-6 tahun sebanyak 24\%, dan bekerja selama 1-3 tahun berjumlah $12 \%$ serta sisanya sebesar 5\% yang baru bekerja selama kurang dari 1 tahun. Berdasarkan lamanya bekerja sebagai manajer pajak di perusahaan tbk ini sebesar 9\% untuk jabatan manajer pajak kurang dari 1 tahun, telah menjabat sebagai manajer pajak selama 1-3 tahun sebanyak 22\%. Sedangkan selama 4-6 tahun menjadi manajer pajak di perusahaan tbk ini sebanyak 35\%, dan 7-10 tahun berjumlah 9\% serta sisanya sebesar 25\% telah menjabat sebagai manajer pajak selama lebih dari 10 tahun. Hal ini berarti ada yang sebelumnya telah bekerja di perusahaan tbk ini kemudian diangkat untuk menduduki jabatan manajer pajak tetapi ada juga yang langsung diterima untuk menduduki jabatan manajer pajak. Sebagian besar manajer pajak mengisi SPT pribadinya sendiri tanpa bantuan pihak lain sebanyak $87 \%$, sedangkan sisanya sebesar $13 \%$ yang dibantu oleh pihak lain dalam pengisian SPT pribadinya.

Tabel 6. Deskripsi demografis data manajer pajak

\begin{tabular}{|c|c|c|c|}
\hline Keterangan & Kelompok & Jumlah responden & Persentase $(\%)$ \\
\hline \multirow[t]{6}{*}{ Pendidikan formal } & SMA & 0 & 0 \\
\hline & D3 & 0 & 0 \\
\hline & $\mathrm{S} 1$ & 73 & 71 \\
\hline & S2 & 28 & 27 \\
\hline & S3 & 2 & 2 \\
\hline & total & 103 & 100 \\
\hline \multirow[t]{3}{*}{ Pendidikan non formal } & brevet \& USKP & 90 & 87 \\
\hline & tidak brevet \& USKP & 13 & 13 \\
\hline & total & 103 & 100 \\
\hline Lamanya bekerja di & $<1$ tahun & 5 & 5 \\
\hline \multirow{2}{*}{ perusahaan ini } & $1-3$ tahun & 12 & 12 \\
\hline & $4-6$ tahun & 25 & 24 \\
\hline
\end{tabular}




\begin{tabular}{llll}
\hline & $7-10$ tahun & 20 & 19 \\
& $>10$ tahun & 41 & 40 \\
& total & 103 & 100 \\
Lama bekerja sebagai & $<1$ tahun & 9 & 9 \\
manajer pajak di & $1-3$ tahun & 23 & 22 \\
perusahaan ini & $4-6$ tahun & 36 & 35 \\
& $7-10$ tahun & 9 & 9 \\
& $>10$ tahun & 26 & 25 \\
& total & 103 & 100 \\
\hline
\end{tabular}

\section{Sumber: Data kuesioner}

Variabel kualitas manajer pajak mempunyai dua dimensi (Zuber, 2007). Pertama, dimensi kompetensi, yang terdiri dari tingkat pendidikan baik formal maupun non formal dibidang perpajakan, lamanya bekerja di perusahaan tersebut dan lamanya menjadi manajer pajak di perusahaan yang dijadikan dalam indikator dummy pertama (dummy_LK). Kemudian, indikator berikutnya adalah (1) ikut berpartisipasi mengisi SPT badan tempat bekerja, (2) ikut berpartisipasi melakukan penghematan pajak dalam setiap transaksi bisnis, dan (3) menggunakan jasa konsultan pajak. Berikutnya adalah pengisian SPT pribadi yang dijadikan indikator dummy kedua (dummy_SPT). Selanjutnya adalah indikator (4) mengisi SPT pajak untuk pribadi dan (5) pengisian SPT pribadi dibantu oleh pihak ketiga diluar perusahaan. Dimensi kedua dari variabel kualitas manajer pajak ini mempunyai tiga indikator (Zuber, 2007). Pertama, taat aturan dan SOP. Kedua, memeriksa diri sendiri. Dan ketiga adalah rekan-rekan yang taat aturan. Hasil analisis deskriptif dimensi komitmen variabel kualitas manajer pajak dapat dilihat pada Tabel 7 dibawah ini.

Tabel 7. Deskripsi variabel kualitas manajer pajak (x1)

\begin{tabular}{|c|c|c|c|c|c|c|}
\hline \multirow{3}{*}{ Indikator } & \multicolumn{5}{|c|}{ Skor jawaban responden } & \multirow{3}{*}{ Mean } \\
\hline & 1 & 2 & 3 & 4 & 5 & \\
\hline & $\%$ & $\%$ & $\%$ & $\%$ & $\%$ & \\
\hline $\begin{array}{l}\text { ikut berpartisipasi mengisi SPT badan tempat } \\
\text { bekerja }\end{array}$ & 1.41 & 3.28 & 0.00 & 40.28 & 55.04 & 4.15 \\
\hline $\begin{array}{l}\text { ikut berpartisipasi melakukan penghematan } \\
\text { pajak dalam setiap transaksi bisnis }\end{array}$ & 6.24 & 1.07 & 1.87 & 39.57 & 51.25 & 3.63 \\
\hline menggunakan jasa konsultan pajak & 0.96 & 2.87 & 2.87 & 52.63 & 40.67 & 4.06 \\
\hline $\begin{array}{l}\text { pengisian SPT pribadi tidak dibantu / mengisi } \\
\text { sendiri }\end{array}$ & 0.94 & 1.88 & 7.26 & 38.17 & 51.75 & 4.13 \\
\hline $\begin{array}{l}\text { pengisian SPT pribadi dibantu oleh pihak } \\
\text { ketiga diluar perusahaan }\end{array}$ & 0.00 & 0.00 & 33.67 & 40.82 & 25.51 & 3.77 \\
\hline dimensi kompetensi & & & & & & 3.96 \\
\hline taat aturan dan SOP & 0.22 & 0.22 & 6.73 & 39.01 & 53.81 & 4.33 \\
\hline memeriksa diri sendiri & 0.35 & 0.47 & 13.41 & 40.47 & 45.29 & 4.13 \\
\hline rekan-rekan taat aturan & 0.25 & 0.74 & 17.65 & 49.51 & 31.86 & 3.96 \\
\hline dimensi komitmen & & & & & & 4.14 \\
\hline Mean score variable & & & & & & 4.05 \\
\hline
\end{tabular}

Sumber: Lampiran 1

Skor rata-rata untuk dimensi kompetensi sebesar 3.96 yang mengartikan bahwa para manajer pajak setuju atau mengakui kompetensi yang dimilikinya. Namun, mereka masih tetap menggunakan jasa konsultan pajak terutama untuk jasa pendampingan yang 
menyangkut pemeriksaan pajak, keberatan, banding ataupun penyelesaian perkara di pengadilan pajak. Hal ini terlihat pada skor angka 4.06 dimana skor tersebut lebih tinggi daripada skor rata-rata dimensi kompetensi.

Sedangkan skor rata-rata dimensi komitmen lebih tinggi yaitu sebesar 4.14 yang menunjukkan bahwa manajer pajak setuju dengan mengakui bahwa mereka memliki komitmen yang tinggi terhadap perusahaan tempatnya bekerja. Hal ini konsisten dengan indikator taat aturan dan SOP yang memiliki skor 4.33. Dari uraian diatas dapat disimpulkan bahwa manajer pajak memiliki kualitas yang baik dengan skor rata-rata variabel kualitas manajer pajak sebesar 4.05 dengan komitmen terhadap perusahaan yang cukup tinggi walaupun kompetensi yang dimiliki agak kurang up date sehingga harus dibantu dengan konsultan pajak.

Ada tiga indikator pada variabel etika Machiavellian ini (Shafer dan Simmons, 2008). Pertama, kepribadian yang kurang afeksi dalam hubungan personal. Kedua, mengabaikan moralitas konvensional. Dan ketiga adalah konsep komitmen yang rendah. Hasil analisis deskriptif variabel etika Machiavellian untuk kualitas manajer pajak dapat dilihat pada tabel dibawah ini.

Tabel 8. Deskripsi variabel etika Machiavellian dari manajer pajak

\begin{tabular}{|c|c|c|c|c|c|c|}
\hline \multirow[b]{2}{*}{ Indikator } & \multicolumn{5}{|c|}{ Skor jawaban responden } & \multirow[b]{2}{*}{ Mean } \\
\hline & 1 & 2 & 3 & 4 & 5 & \\
\hline $\begin{array}{l}\text { kepribadian yang kurang afeksi dalam } \\
\text { hubungan personal }\end{array}$ & 1.76 & $\frac{\%}{8.60}$ & 17.92 & 46.18 & 25.53 & 3.49 \\
\hline mengabaikan moralitas konvensional & 1.20 & 9.13 & 15.67 & 42.09 & 31.91 & 3.59 \\
\hline konsep komitmen yang rendah & 2.50 & 15.14 & 17.71 & 45.72 & 18.93 & 3.21 \\
\hline Mean score variable & & & & & & 3.43 \\
\hline
\end{tabular}

Sumber: Lampiran 3

Indikator "konsep komitmen yang rendah" memiliki skor sebesar 3.21. Nilai skor ini mengindikasikan bahwa manajer pajak mempunyai kecenderungan tidak setuju dengan konsep komitmen yang rendah. Walaupun manajer pajak cenderung setuju untuk mengabaikan moralitas konvensional. Hal ini terjadi karena kepribadian manajer pajak yang masih cenderung kurang peka dengan lingkungannya. Dari uraian diatas dapat disimpulkan bahwa persepsi manajer pajak terhadap etika Machiavellian masih cenderung tidak setuju dengan ajaran Machiavellian dalam pandangan etika dengan ditunjukkan oleh nilai 3.43 .

Deskriptif Statistik Data Sekunder Penghindaran pajak. Deskriptif statistik digunakan untuk mendeskriptifkan variabel-variabel yang digunakan dalam penelitian. Deskriptif statistik dilakukan dengan SPSS 20. Variabel dependen penghindaran pajak diproksikan dalam 10 indikator yaitu current ETR, GAAP ETR, cash ETR, tax ETR, GPM, OPM, PPM, CCTOR, NPM dan DPR. Jumlah pengamatan yang digunakan untuk penelitian yaitu berjumlah 598 untuk penghindaran pajak. Hasil deskriptif statistik data sekunder disajikan pada Tabel 9 berikut ini. 
Tabel 9. Hasil deskriptif statistik variabel penghindaran pajak

\begin{tabular}{lllll}
\hline Nama variabel & Minimum & Maximum & Mean & Std. Deviation \\
\hline current ETR & -3.7100 & 6.1500 & 0.1966 & 0.3956 \\
GAAP ETR & -4.3300 & 6.6000 & 0.2441 & 0.5429 \\
cash ETR & -22.6000 & 37.0600 & 0.4717 & 2.6065 \\
tax ETR & -81.2100 & 41.4600 & -0.2367 & 4.0494 \\
GPM & -2.4200 & 4.6900 & 0.1879 & 0.3112 \\
OPM & -4.4100 & 2.5400 & 0.0481 & 0.3563 \\
PPM & -9.4400 & 1.7500 & 0.0041 & 0.6055 \\
CCTOR & -8.4500 & 0.0030 & -0.0195 & 0.3519 \\
NPM & -9.4000 & 6.3800 & 0.0113 & 0.5847 \\
DPR & -4.4400 & 11.2300 & 0.2110 & 0.6538 \\
\hline
\end{tabular}

Sumber: Data diolah SPSS 20

Variabel penghindaran pajak dalam penelitian ini menggunakan 10 indikator. Semua nilai minimum dari angka rasio variabel penghindaran pajak menunjukkan bahwa ada perusahaan yang berusaha melakukan strategi penghindaran pajak terindikasi risiko pemeriksaan pajak oleh pihak aparat pajak, sedangkan nilai maksimum menunjukan bahwa perusahaan kemungkinan melakukan strategi penghindaran pajak yang kecil risikonya.

Nilai rata-rata variabel penghindaran pajak dengan ukuran tax ETR dan CCTOR bernilai negatif, yang berarti bahwa perusahaan sampel rata-rata dalam kondisi lebih bayar (PPh 28a). Hal ini disebabkan karena ukuran tax ETR dan CCTOR menggunakan pajak terutang (PPh 29) dalam menghitung besarnya penghindaran pajak. Terjadinya lebih bayar tersebut dikarenakan kredit pajak yang lebih besar seperti pemotongan pajak yang telah dilakukan oleh pihak ketiga ataupun dikarenakan kelebihan angsuran pajak (PPh 25) ataupun karena pengakuan PPh 28a yang dilakukan tahun-tahun sebelumnya.

Pengolahan data dan hipotesis. Pengujian $\mathrm{H} 1$ untuk menguji pengaruh kualitas manajer pajak terhadap penghindaran pajak. Variabel kualitas manajer pajak merupakan variabel manifest yang mempresentasikan dua indikator berupa kompetensi dan komitmen. Sedangkan variabel penghindaran pajak mempresentasikan sepuluh indikator. Hasil outer model untuk cross-loading ukuran refleksif individual untuk variabel kualitas manajer pajak dikatakan tinggi karena memiliki nilai masing-masing 0.737. Tetapi untuk variabel penghindaran pajak masih ada yang memiliki nilai kurang dari 0.50 dengan konstruk yang ingin diukurnya, sehingga tax ETR, current ETR, GAAP ETR, cash ETR, dan CCTOR serta DPR yang memiliki nilai dibawah 0.5 harus dihapus. Setelah dihapus enam maka tersisa empat indikator yaitu GPM, OPM, PPM dan NPM dengan nilai sebesar 0.642; 0.923; 0.969 dan 0.941.

Sedangkan hasil outer model dari nilai AVE, composite reliability dan cronbach's alpha untuk variabel kualitas manajer pajak dan penghindaran pajak adalah seperti Tabel 10 ini.

Pengujian inner model dilakukan dengan melihat nilai $R$-square yang merupakan uji goodness-fit-model pada model pengaruh kualitas manajer pajak terhadap penghindaran pajak, yaitu nilai ARS sebesar 0.004 dengan P sebesar 0.231 dan AARS sebesar 0.002 dengan P sebesar 0.242; yang berarti bahwa nilai R2 sebesar 0.004 menunjukkan variabel 
penghindaran pajak hanya sebesar $0.4 \%$ dapat terjelaskan oleh variansi kualitas manajer pajak.

Tabel 10. Hasil koefisien variabel laten $\mathrm{H} 1$

\begin{tabular}{llllllll}
\hline & $\begin{array}{l}\text { R-squared } \\
\text { coefficients }\end{array}$ & $\begin{array}{l}\text { Adjusted } \\
\text { R-squared } \\
\text { coefficient } \\
\text { s }\end{array}$ & $\begin{array}{l}\text { Composite } \\
\text { reliability } \\
\text { coefficients }\end{array}$ & $\begin{array}{l}\text { Cronbach's } \\
\text { alpha } \\
\text { coefficients }\end{array}$ & $\begin{array}{l}\text { Average } \\
\text { variances } \\
\text { extracted }\end{array}$ & $\begin{array}{l}\text { Full } \\
\text { collinearity } \\
\text { VIFs }\end{array}$ & $\begin{array}{l}\text { Q- } \\
\text { squared } \\
\text { coeffici } \\
\text { ents }\end{array}$ \\
\hline K_mjr & - & - & 0.704 & 0.158 & 0.543 & 1.265 & - \\
d_LK & - & - & 1.000 & 1.000 & 1.000 & 1.248 & - \\
d_SPT & - & - & 1.000 & 1.000 & 1.000 & 1.014 & - \\
P_Pajak & 0.004 & -0.002 & 0.930 & 0.894 & 0.772 & 1.003 & 0.004 \\
\hline
\end{tabular}

Sumber: Data diolah Warp PLS 5.0

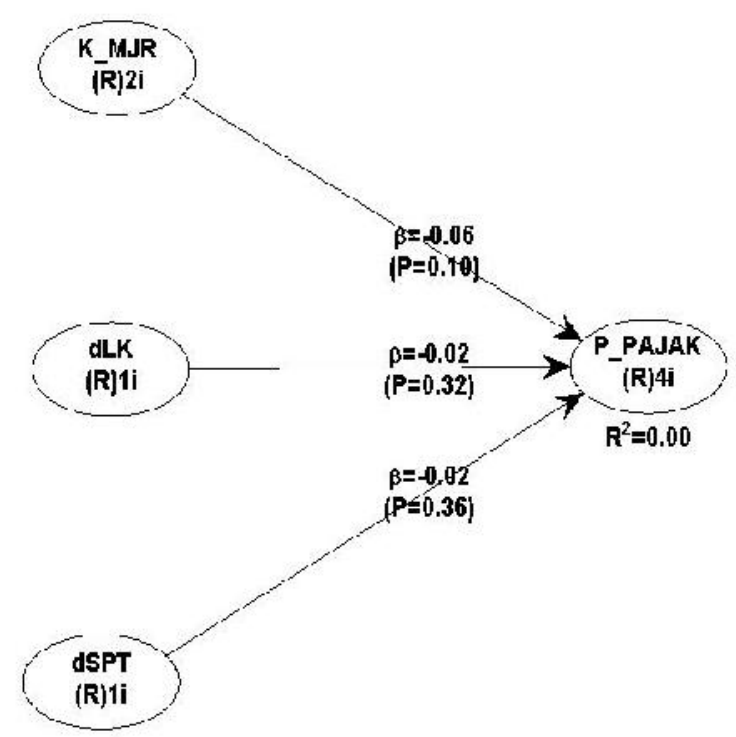

Gambar 1. Pengaruh kualitas manajer pajak terhadap penghindaran pajak

Berdasarkan Gambar 1 diatas dapat dijelaskan bahwa tidak ada pengaruh langsung kualitas manajer pajak terhadap penghindaran pajak karena tidak signifikan yang dapat dilihat pada nilai $\mathrm{p}$ sebesar 0.103 . Hasil pengujian $\mathrm{H} 1$ ini memiliki nilai t-Statistic sebesar 0.103 yang lebih besar dari $10 \%$, maka $\mathrm{H} 1$ tidak berhasil menolak $\mathrm{H}_{0}$ yang berarti bahwa tidak terdapat pengaruh variabel independen terhadap variabel dependen (Nachrowi \& Usman, 2006). Hipotesis penelitian tidak berhasil didukung data yang dapat dikatakan bahwa H1 ditolak. Manajer pajak di perusahaan yang terdaftar di BEI tidak terbukti ikut serta dalam melakukan upaya menghemat pajak yang harus dibayar perusahaan dengan strategi penghindaran pajak. Hal ini dapat dikarenakan sebagian besar manajer pajak sebanyak $71 \%$ dalam penelitian ini memiliki tingkat pendidikan formal S1 atau sarjana. Menurut Ross dan MCGee (2012) semakin rendah tingkat pendidikan seseorang maka akan semakin menentang tindakan penghindaran pajak. Tetapi, saat seseorang memiliki tingkat pendidikan yang tinggi maka akan semakin banyak pengetahuannya yang akan memberikan keuntungan dalam melakukan penghindaran pajak.

Sebelum pengujian $\mathrm{H} 2$ dlakukan dahulu pengujian inner model dapat dilakukan dengan melihat nilai $R$-square yang merupakan uji goodness-fit-model pada model 
pengaruh kualitas manajer pajak terhadap penghindaran pajak melalui etika Machiavellian seperti pada Tabel 4.8 ini. Namun,secara keseluruhan hasil ARS adalah sebesar 0.038 dengan P sebesar 0.096 dan AARS sebesar 0.032 dengan $P$ sebesar 0.117 yang berarti bahwa variabel penghindaran pajak hanya sebesar 3.8\% dapat terjelaskan oleh variansi kualitas manajer pajak melalui etika Machiavellian.

Tabel 11. Hasil koefisien variabel laten $\mathrm{H} 2$

\begin{tabular}{llllllll}
\hline & $\begin{array}{l}\text { R-squared } \\
\text { coefficients }\end{array}$ & $\begin{array}{l}\text { Adjusted } \\
\text { R-squared } \\
\text { coefficients }\end{array}$ & $\begin{array}{l}\text { Composite } \\
\text { reliability } \\
\text { coefficients }\end{array}$ & $\begin{array}{l}\text { Cronbach's } \\
\text { alpha } \\
\text { coefficients }\end{array}$ & $\begin{array}{l}\text { Average } \\
\text { variances } \\
\text { extracted }\end{array}$ & $\begin{array}{l}\text { Full } \\
\text { collinearity } \\
\text { VIFs }\end{array}$ & $\begin{array}{l}\text { Q-squared } \\
\text { coefficients }\end{array}$ \\
\hline K_mjr & - & - & 0.704 & 0.158 & 0.543 & 1.265 & - \\
d_LK & - & - & 1.000 & 1.000 & 1.000 & 1.456 & - \\
d_SPT & - & - & 1.000 & 1.000 & 1.000 & 1.016 & - \\
EMach & 0.070 & 0.065 & 1.000 & 1.000 & 1.000 & 1.205 & 0.240 \\
P_Pajak & 0.007 & -0.001 & 0.930 & 0.894 & 0.772 & 1.005 & 0.007 \\
\hline
\end{tabular}

Sumber: Data diolah WarpPLS 5.0

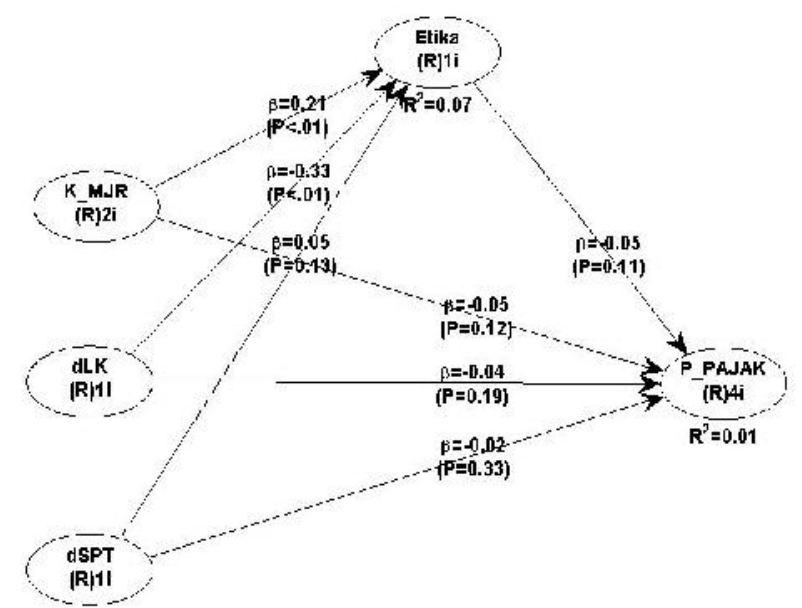

Gambar 2. Pengaruh kualitas manajer pajak terhadap penghindaran pajak melalui etika machiavellian

Gambar 2 diatas dapat dijelaskan bahwa pengaruh total kualitas manajer pajak terhadap penghindaran pajak melalui etika machiavellian adalah sebesar -0.05 atau -0.063 seperti pada tabel 4.9 atau yang didapati dari hasil perhitungan pengaruh tidak langsung dengan pengaruh langsung tanpa melalui variabel etika machivellian seperti di bawah ini.

Pengaruh tidak langsung $=0.208 * \mathrm{x}-0.053$ $-0.011024$

$\mathrm{x} 3 \rightarrow \mathrm{eMach}=0.208^{*} ;$ eMach $\rightarrow$ penghindaran pajak $=-0.053$

Pengaruh langsung $(\mathrm{x} 3 \rightarrow$ penghindaran pajak, tanpa eMach) $\quad-0.055$

Pengaruh total $=$ $-0.066024$

Berdasarkan perhitungan di atas maka dapat disimpulkan bahwa variabel etika Machiavellian lebih mempengaruhi kualitas manajer pajak daripada penghindaran pajak karena dilihat dari hasil pengaruh kualitas manajer pajak terhadap etika Machiavellian yang signifikan. Belum adanya pengaruh etika Machiavellian terhadap penghindaran pajak karena nilai rata-rata indikator penghindaran pajak dari GPM, OPM, PPM dan NPM sebesar $0.1879 ; 0.0481 ; 0.0041$ dan 0.0113 pada tabel 4.6 hanya NPM saja yang 
memperhitungkan unsur pajak dengan memperhitungkan beban Pajak Penghasilan badan yang terdapat dalam laporan laba rugi komprehensif perusahaan.

Pengaruh kualitas manajer pajak terhadap etika machiavellian adalah sebesar 0.208 karena memiliki signifikan pada tingkat $99 \%$ yang dapat dilihat pada nilai p sebesar $<0.01$. Hal ini menunjukkan bahwa kompetensi yang dimiliki manajer pajak dan komitmennya pada perusahaan mendominasi kualitas dari manajer pajak untuk mendukung keputusan manajemen puncak (Zuber, 2007; Waegenaere, et a;. 2013) agar mendapatkan peningkatan kompensasi oleh manajemen puncak (Amstrong, et al. 2011) dengan mengorbankan kepentingan publik (He \& Ho, 2010; Stuebs \& Wilkinson, 2010; Alm \& Togler, 2011). Pengabaian nilai-nilai etika deontologi yang dapat dilihat dengan semakin mengutamakan keegoisan (Shafer \& Simmons, 2008), mengindikasikan bahwa masih rendahnya peekembangan moral seseorang (Kohlber, 1981). Hasil ini didukung dengan hasil deskriptif kuesioner variabel etika Machiavellian pada tabel 4.5 dimana rata-rata indikator "mengabaikan moralitas konvensional" sebesar 3.59 yang dapat diartikan bahwa para manajer pajak cenderung setuju dengan paham etika Machiavellian yang menghalalkan segala cara untuk mendapatkan kesejahteraan.

Untuk para manajer yang baru bekerja di perusahaan maka sang manajer cenderung memiliki keinginan untuk lebih menyenangkan manajemen puncak atau dengan kata lain manajer yang baru bergabung di perusahaan akan semakin ingin menunjukkan kompetensi dan komitmennya di mata sang manajemen puncak (Zuber, 2007; Waegenaere, et a; 2013) agar memperoleh kompensasi yang lebih dari manajemen puncak (Amstrong, et al. 2011) yang sejalan dengan etika machiavellian (Stuebs \& Wilkinson, 2010). Hal ini didukung dengan hasil pengolahan data yang menunjukkan hasil arah negatif sebesar 0.334 dengan tingkat kepercayaan 99\%. Hasil arah negatif ini terjadi karena sebagian besar atau lebih dari $50 \%$ responden dalam penelitian ini telah bekerja lebih sampai dengan lima tahun sebagai manajer pajak di perusahaan seperti pada tabel 4.3 yang dapat diartikan bahwa kompetensi dan komitmen mereka telah diketahui dan diakui oleh manajemen puncak sehingga mereka tidak perlu bersusah payah lagi untuk mendapatkan kompensasi sebagai peningkatan kesejahteraan.

Pengujian H2 ini dilakukan untuk menguji pengaruh etika machiavellian sebagai variabel mediasi. Namun, sebelumnya ada syarat yang harus dipenuhi yaitu hasil pengujian pengaruh langsung kualitas manajer pajak terhadap penghindaran pajak haruslah signifikan. Syarat ini tidak terpenuhi, disebabkan karena hasil pengujian pengeruh langsung kualitas manajer pajak terhadap penghindaran pajak atau H1 tidak signifikan. Hasil pengujian H1 mempunyai p-values sebesar 0.103; 0.316 dan 0.363 maka pengujian pengaruh mediasi tidak dapat dilanjutkan.

Tabel 12. Hasil pengujian $\mathrm{H} 2$

\begin{tabular}{lll}
\hline & Koefisien & P-values \\
\hline Tabel koefisien & & \\
K_mjr $\rightarrow$ EMach & $0.208^{*}$ & $<0.001$ \\
dummy_LK $\rightarrow$ EMach & $-0.334^{*}$ & $<0.001$ \\
dummy_SPT $\rightarrow$ EMach & 0.049 & 0.130 \\
K_mjr $\rightarrow$ P_Pajak & -0.052 & 0.117 \\
dummy_LK $\rightarrow$ P_Pajak & -0.039 & 0.190 \\
dummy_SPT $\rightarrow$ P_Pajak & -0.019 & 0.334 \\
\hline
\end{tabular}




\begin{tabular}{lll}
\hline EMach $\rightarrow$ P_Pajak & -0.053 & 0.112 \\
Tabel total effect & & \\
K_mjr $\rightarrow$ EMach & $0.208^{*}$ & $<0.001$ \\
dummy_LK $\rightarrow$ EMach & $-0.334^{*}$ & $<0.001$ \\
dummy_SPT $\rightarrow$ EMach & 0.049 & 0.130 \\
K_mjr $\rightarrow$ P_Pajak & $-0.063^{* * *}$ & 0.074 \\
dummy_LK $\rightarrow$ P_Pajak & -0.021 & 0.319 \\
dummy_SPT $\rightarrow$ P_Pajak & -0.021 & 0.313 \\
EMach $\rightarrow$ P_Pajak & -0.053 & 0.112 \\
\hline
\end{tabular}

Sumber: Data diolah Warp PLS 5.0

Karena pengujian pengaruh langsung kualitas manajer pajak terhadap penghindaran pajak tidak memenuhi syarat signifikan maka pengujian mediasi pada $\mathrm{H} 2$ tidak dapat dilakukan sehingga dapat dikatakan bahwa hipotesis mediasi ditolak.

\section{PENUTUP}

Simpulan. Penelitian ini menguji pengaruh langsung dan tidak langsung kualitas manajer pajak terhadap penghindaran pajak. Dalam penelitian ini menggunakan data primer berupa kuesioner dari 120 manajer pajak dan konsultan pajak dari perusahaan industri yang terdaftar di BEI selama 4 tahun selama periode 2010-2014. Namun, hanya 103 kuesioner yang berasal dari manajer pajak $(85.84 \%)$ yang dapat diisi dan diolah untuk penelitian ini.

Penelitian ini menggunakan kualitas manajer pajak sebagai variabel independen dan penghindaran pajak sebagai variabel dependen. Sedangkan etika machiavellian digunakan sebagai variabel mediasi. Hasil penelitian ini untuk $\mathrm{H} 1$ dan $\mathrm{H} 2$ adalah pengaruh langsung maupun tidak langsung kualitas manajer pajak terhadap penghindaran pajak belum terdukung data. Atau bisa dikatakan bahwa belum ada pengaruh langsung maupun melalui etika Machiavellian pada kualitas manajer pajak terhadap penghindaran pajak.

Penelitian ini masih memiliki beberapa kelemahan yaitu variabel kualitas manajer pajak masih menggunakan dimensi kompetensi teknis saja padahal dapat ditambahkan untuk dimensi kompetensi moral. Juga kuesioner etika machiavellian dalam penelitian ini belum menggunakan mini kasus untuk lebih mempertajam pendapat respon dari responden. Dengan masih adanya beberapa kelemahan tersebut maka hasil penelitian ini masih belum dapat digeneralisir

Demikian juga pembatasan variabel-variabel yang tidak dimasukkan dalam penelitian ini. Hal ini dapat dilihat pula dari hasil R-Square dalam penelitian ini masih memiliki nilai sekitar 3.2\% sehingga variabel penghindaran pajak kebanyakan dipengaruhi oleh variabel lain diluar kualitas manajer pajak dan etika machiavellian yang masih banyak yang lain; seperti yang dihasilkan oleh para peneliti di Indonesia sehingga menjadikan hasil penelitian ini belum sempurna.

Saran. Disarankan bagi penelitian yang akan datang dengan menambah jumlah sampel penelitian, menggunakan indikator kemampuan manajer pajak yang berasal dari penelitian Ko, Park dan Jung (2014) dengan ukuran dari Demerjian, Lev dan McVay (2012) yang menggunakan data sekunder dari laporan keuangan sehingga hasil penelitian akan lebih akurat serta variabel penelitian yang lebih lengkap agar dapat mengungkapkan variabelvariabel yang mempengaruhi penghindaran pajak sehingga memperkaya kajian bagi 
literatur akademis dibidang penelitian keperilakuan serta dapat memberikan manfaat kepada regulator serta pemerintah dalam menentukan arah kebijakan jangka panjang.

\section{DAFTAR RUJUKAN}

Abadi, K. \& Gunawan, J. (2014) Content Analysis Method: A Proposed Guideline for Quantitative and Qualitative Disclosures. Handbook of Research Methods in SCR. Edward Elgar.

Alm, J. \& Torgler, B. (2011) "Do Ethics Matter? Tax Compliance and Morality". Journal of Business Ethics, 101, 635-651.

Aliani, K. \& Zarai, M. A. (2012) "Demographic Diversity in the Board and Corporate Tax Planning in American Firm". Business Management and Strategy, 3 (1),72-86.

Annisa, N. A. \& Kurniasih, L. (2012) "Pengaruh Tata kelola terhadap Penghindaran Pajak". Jurnal Akuntansi dan Auditing, 8 (2), Mei, 123-136.

Armstrong, C. S., Blouin J. L. \& Larcker, D. F. (2011) The Incentives for Tax Planning. http://ssrn.com. (diakses 24 Juni 2014).

Armstrong, C. S., Blouin, J. L., Jagolinzer, A. D. \& Larcker, D. F. (2014) Corporate Governance, Incentives, and Tax Avoidance. http://ssrn.com. (diakses September 2014).

Andreoni, J., Erard, B. \& Feinstein, J. (1998) "Tax Compliance". Journal of Economic Literature, XXXVI, June, 818-860.

Ba, S. \& Pavlou, P. A. (2002) "Evidence of the Effect of Trust Building Technology in Electronic Markets: Price Premiums and Buyer Bahavior". MIS Quarterly, 26, 243268.

Badertscher, B.A., Katz, S.P. \& Rego, S.O. (2012) "The Separation of Ownership and Control and Corporate Tax Avoidance". Columbia Business School Research Paper.13-64.

Balakrishnan, K., Blouin, J. \& Guay, W. (2012) Does Tax Aggressiveness Reduce Corporate Transparency? http://ssrn.com. (diakses 3 September 2014).

Bertens, K. (2013) Etika, edisi revisi, Yogyakarta: PT Kanisius.

Bertolini, M. S., Higgs, J. L. \& Hooks, K. L. (2011) Multidimensional Locus of Control Applied to the Taxpayer/Tax Professional Relationship. Advances in Accounting Behavioral Research, 14, Emerald Group Publishing Limited, 1 - 35.

Binaj, I. (2015) "An Evaluation of the Impact of Corruption, Tax Burden, and Income on the Size of the Shadow Economy". International Journal of Accounting and Taxation, 3 (2), 15-27.

Blanthorne, C., Burton, H. A. \& Fisher, D. (2014) "The Aggressiveness of Tax Professional Reporting: Examining the Influence of Moral Reasoning. Advances in Accounting Behavioral Research, 16, Emerald Group Publishing Limited, 149 - 181.

Bobek, D., Hageman, A. \& Hatfield, R. (2010) "The Role of Client Advocacy in the Development of Tax Professionals' Advice". The Journal of the American Taxation Association, 32, (1), 25.

Bolt, C. E. (2005) Ethics Standards for the Professional Tax Practice: New Developments. Proceedings of the Academy of Accounting and Financial Studies, 10, 2, Las Vegas, Nevada. 
Budiman, J. \& Setiono. (2012) "Pengaruh Karakter Eksekutif terhadap Penghindaran Pajak (Tax Avoidance)". Simposium Nasional Akuntansi XV. Banjarmasin.

Chen, S., Chen, X., Cheng, Q. \& Shevlin, T. (2008) Are family firms more tax aggressive than non-family firms? http://ssrn.com. (diakses 13 Oktober 2013).

Chen, S., Chen, X., Cheng, Q. \& Shevlin, T. (2010) "Are family firms more tax aggressive than non-family firms?" Journal of Financial Economics, 95 (1), 41-61.

Chen, K. P. \& Chu, C. Y. C. (2005) "Internal Control vs External Manipulation: A Model of Corporate Income Tax Evasion". Rand Journal of Economics. Spring, 36 (4), 151164.

Chyz, J.. Leung, W. S. C., Li, O. Z. \& Rui, O. M. (2013) "Labor Unions and Tax Aggressiveness". Journal of Financial Economics (JFE), 108, 3.

Chyz, J. A. \& White, S. D. (2014) The Association between Agency Conflict and Tax Avoidance: A Direct Approach, in Toby Stock (ed.) Advances in Taxation, 21 Emerald Group Publishing Limited, $107-138$.

Chyz, J. F., Kausar, G. A. \& Watson, L. (2014) "Overconvidence and Aggressive Corporate Tax Policy". Working Paper, University of Tennessee, University of Wisconsin, and Nanyang Technological University.

Coles, J.L., Daniel, N. D. \& Naveen, L. (2004) Managerial Incentives and Risk-Taking.

Crabbé, K. (2010) The Impact of The Auditor and Tax Advice on The Effective Tax Rate. Department of Accountancy, Finance and Insurance (AFI) Faculty of Business and Economics Katholieke Universiteit LEUVEN.

Crocker, K. J. \& Slemord, J. (2005) "Corporate Tax Evasion With Agency Costs". Journal of Public Economics, 89, 1593 - 1610.

Crossman, H. A. (2008) "A Comparative Analysis of the Cognitive Moral Development of Independent Public Auditors in Selected Public Accounting Firms and Bank Examiners in Selected Federal Banking Regulatory Agencies". Dissertation from School of Business and Entrepreneurship, Nova Southeastern University.

Daniri, M. A. (2005) Good Corporate Governance: Konsep dan Penerapannya dalam Konteks Indonesia, Jakarta: Gloria Printing.

Darussalam, D. (2009) Tax Planning, Tax Avoidance, dan Tax Evasion. www.ortax.org. (diakses 11 November 2016)

Demerjian, P., Lev, B. \& McVay, S. (2012) "Quantifying Managerial Ability: A New Measure and Validity Tests". Management Science, 58 (7), July, 1229-1248.

Desai, M. A. \& Dharmapala, D. (2004) Corporate Tax Avoidance and High Powered Incentives, http://digitalcommons.uconn.edu. (diakses 21 Juli 2013).

Desai, M. A. \& Dharmapala, D. (2005) "Corporate Tax Avoidance and Firm Value". Working Paper National Bureau of Economic Research. http://www.nber.org. (diakses 21 Juli 2013).

Desai, M. A. \& Dharmapala, D. (2006) "Corporate Tax Avoidance and High Powered Incentives". Journal of Financial Economics, 79, 145-179.

Desai, M. A. \& Dharmapala, D. (2007) Taxation and Corporate Governance: An Economic Approach. http://papers.ssrn.com. (diakses 21 Juli 2013).

de Santo, J. \& Cremers SVD, A. (1995) Tahap-tahap Perkembangan Moral Lawrence Kohlberg. Yogyakarta: Penerbit Kanisius. 
DeZoort, T. F., Harrison, P. D. \& Schnee, E. J. (2012) “Tax Professionals' Responsibility for Fraud Detection: The Effects of Engagement Type and Audit Status". Accounting Horizons, 26 (2), 289-306.

Dharmasaputra, M. (2013) Saksi Kunci Kisah nyata perburuan Vincent, pembocor rahasia pajak Asian Agri Group. Penerbit Tempo.

Dianawati, N. M. D. \& Ramantha, W. (2013) "Pengaruh Independensi, Keahlian Profesional Terhadap Efektifitas Struktur Pengendalian Internal Bank Perkreditan Rakyat di Kabupaten Gianyar". E-Jurnal Akuntansi Universitas Udayana, 4 (3), 439-450.

Dominguez, L. R., Alvarez, I. G. \& Sanchez, I. M. G. (2009) “Corporate Governance and Codes of Ethics", Journal of Business Ethics, 90, 187-202.

Doyle, E., Hughes, J. F. \& Summers, B. (2014) "Ethics in Tax Practice: A Study of the Effect of Practitioner Firm Size". Journal Bussines Ethics, 122, 623-641.

Dunham, L. M. \& Washer, K. (2012) "The Ethics of Hedging by Executives". Journal Bussines Ethics, 111, 157-164.

Dunn, P. (1999) Fraudulent Financial Reporting: A Deception Based on Predisposition, Motive and Opportunity. Dissertation from Boston University.

Dyreng, S. D., Hanlon, M. \& Maydew, E. L. (2008) "Long run corporate tax avoidance". The Accounting Review. 83, 61-82.

Dyreng, S. D., Hanlon, M. \& Maydew, E. L. (2010) "The Effect of Executives on Corporate Tax Avoidance". The Accounting Review, 85 (4), 1163-1189.

Feng, P. C. (Petrina). (2008) “An Empirical Study of CPA's Moral Development, Ethical Evaluation and Ethical Intention: A Selected Group of Taiwanese CPA's". Dissertation from Maharishi University of Management, Fairfield, Iowa.

Flynn, K. E. (2003) "An Empirical Investigation into Alternative Theories Explaining Taxpayer Behavior". Dissertation from Drexel University.

Frank, M., Lynch, L. \& Rego, S. (2009) "Tax Reporting Aggressiveness and Its Relation to Aggressive Financial Reporting". The Accounting Review, 84 (2), 467-496.

Ferdinand, A. (2005) Structural Equation Modeling. Edisi3. Semarang, BP Undip.

Freedman, J., Loomer, G. \& Vella, J. (2009) Corporate Tax Risk and Tax Avoidance: New Approaches. BTR, 1, Thomson Reuters (Legal) Limited and Contributiors.

Gaertner, F. B. (2011) "CEO After-Tax Compensation Incentives and Corporate Tax Avoidance". Dissertation from The University of Arizona.

Gefen, D. (2000) "E-commerce: the role of familiarity and trust". Omega The International Journal of Management Science, 28, 725-737.

Ghozali, I. (2008) Structural Equation Modeling Metode Alternatif dengan Partial Least Square PLS. Edisi 2.Semarang: Badan Penerbit Universitas Diponegoro.

Graf, R. \& Parrien, J. (2005) The Role of Trust and Satisfication in a Relationship: The Case of High Tecs Firms and Banks. Communication Article.

Graham, J.R., Hanlon, M., Shevlin, T.J. \& Shroff, N. (2011) Incentives for tax planning and avoidance: evidence from the field. MIT Sloan Research Paper, 4990.

Guenther, D. A., Matsunaga, S. R. \& Williams, B. M. (2013) Tax Avoidance, Tax Aggressiveness, Tax Risk and Firm Risk.

Gupta, R. (2009) "An Empirical Study of Demographics of Perception of Tax Evasion in New Zealand". Journal of Australian Taxation, 12 (1).

Hakim, T. (2002) Mengatasi Rasa Tidak Percaya Diri. Jakarta: PuspaSwara. 
Hall, M., Zheng, B., Dugan, E. \& Mishra, A. (2002) Interpersonal Physician Trust Scale. Medical University of South Carolina.

Hanlon, M., Mills, L. \& Slemrod, J. (2005) “An Empirical Examination of Corporate Tax Noncompliance". Ross School of Business Working Paper Series.

Hanlon, M. \& Slemrod, J. (2009) "What does tax aggressiveness signal? Evidence from stock price reactions to news about tax shelter involvement". Journal of Public Economics, 93, 126-141.

Hanlon, M. \& Heitzman, S. (2010) A Review of Tax Reseach. Journal of Accounting and Economics, 50, 127-178.

Hansen, V. J. \& White, R. A. (2012) “An Investigation of the Impact of Preparer Penalty Provisions on Tax Preparer Aggressiveness". JATA, 34 (1), 137-165.

Hartono, J. (2008) Teori Portofolio dan Analisis Investasi. Edisi Kelima. Yogyakarta: BPFE.

Hasibuan, M. (2003) Manajemen Sumber Daya Manusia, Jakarta: PT.Bumi Aksara.

He, L. \& Ho, S. J. K. (2010) "Monitoring Costs, Managerial Ethics and Corporate Governance: A Modeling Approach". Journal of Business Ethics, 99, 623-635.

Healy, P. M. \& Wahlen, J. M. (1999) "A Review of the Earnings Management Literatur and Its Implications for Standard Setting". Accounting Horizons, 13, 365-383.

Heinsman. H., de Hoogh, A. H. B., Koopman, P. L. \& van Muijen, J. J. (2008) "Commitment, Control, and the Use of Competency Management". Personal Review, 37 (6), 609-628.

Hoffman, Jr, W. H. (1961) “The Theory of Tax Planning”, The Accounting Review, 36 (2) April, 274-281.

Hoi, C.K., Wu, Q. \& Zhang, H. (2014) "Is corporate social responsibility (CSR) associated with tax avoidance? Evidence from irresponsible CSR activities". Accounting Review Forthcoming.

Hunt, S. D. \& Chonko, L. B. (1984) "Marketing and Machiavellianism", Journal of Marketing, 48 summer, 30-42.

Hutagaol, J. (2007) "Strategi meningkatkan kepatuhan wajib pajak". Jurnal Perpajakan Indonesia. 6 (2), 186-193.

Ikatan Konsultan Pajak Indonesia. Kode Etik.

Jalan, A., Kale, J. R. \& Meneghetti, C. (2013) Corporate Tax Aggressiveness and the Role of Debt. http://robinson.gsu.edu. (diakses 20 Juni 2014).

Jasfar, F. (2014) Pemasaran Jasa antara Ekspektasi dan Kenyataan: Kumpulan Hasil Penelitian Mengenai Industri Jasa di Indonesia. Jakarta: Universitas Trisakti.

Jensen, M. C. \& Meckling, W. H. (1976) "Theory of The Firm: Managerial Behavior, Agency Cost and Ownership Structure". Journal of Financial Economics, 34, 305360.

Jones, D. \& Fogarty, T. J. (2014) The Devil and The Deep Blue Sea : An Empirical Analysis of Client Advocacy and Governmental Fidelity by Tax Practitioners. American Accounting Association Annual Meeting and Conference on Teaching in Accounting, Atlanta.

Killian, S. \& Doyle, E. (2004) "Tax Aggression among Tax Professionals: The Case of South Africa". Journal of Accounting, Ethics and Public Policy, 4, 3. 
Ko, C. Y., Park, J. \& Jung, H. (2014) "Does the Ability of Managers Affect the Firm's Tax Avoidance?", International Information Institute (Tokyo), 17 (7), July, 29612966.

Koanantachai, R. (2013) "Tax Aggressiveness, Corporate Governance, and Firm Value: An Empirical Evidence from Thailand". Dissertation from Faculty of Commerce and Accountancy Thammasat University, Bangkok, Thailand.

Komite Nasional Kebijakan Governance (KNKG). (2006) Pedoman Umum Good Corporate Governance di Indonesia. Jakarta.

Koski, T. R. (1998) "The Influence of Tax Preparer Psychological Commitment and Client Payment Status on the Aggressiveness of Tax Preparer Decision Making”. Dissertation from University o f Missouri - Columbia.

Krippendorff, K. (2004) Content Analysis An Introduction to Its Methodology. Second Edition. California: Sage Publications, Inc.

Kurniasih, T. \& Ratna Sari, M. M. (2013) "Pengaruh Return on Assets, Leverage, Tata kelola, Ukuran Perusahaan dan Kompensasi Rugi Fiskal pada Tax Avoidance". Buletin Studi Ekonomi, 18, 1, Feb.

Lanis, R. \& Richardson, G. (2011) "Corporate social responsibility and tax aggressiveness: an empirical analysis". Journal of Accounting and Public Policy.

Lawellen, K. (2003) "Financing decisions when managers are risk averse". Working Paper Mit Sloan School of Management.

Leech, N. L., Barret, K. C. \& Morgan, G. A. (2005) SPSS for Inteermediate Statistics: Use and Interpretation. Second Edition. New Jersey: Lawrence Erlabaum Associates Publishers.

Lietz, G. (2013) Tax Avoidance vs. Tax Aggressiveness: A Unifying Conceptual Framework. Working Paper University of Münster. http://ssrn.com. (diakses 24 Juni 2014).

Lim, Y. (2011) Tax Avoidance, Cost of Debt and Share Activism: Evidence from Korea, Journal of Banking \& Finance, 35, 456-470.

Low, A. (2006) Managerial risk-taking behavior and equity-based compensation. Fisher College of Business Working Paper. 3 (3).

Lowry, P. B., Wilson, D. W. \&. Haig, W. L. (2013) "A Picture Worth A Thousand Words: Source Credibility Theory Applied to Logo and Webside Design for Heightened Credibility and Consumer Trust". International Journal of Human Computer Interaction, 30 (1), 63-93.

Lubis, A. I. (2010) Akuntansi Keperilakuan. Edisi 2. Jakarta: Penerbit Salemba Empat.

MacCrimmon, K. R. \& Wehrung, D. A. (1990) Characteristics of Risk Taking Executives, Management Science, 422.

Machold, S, Ahmed P. K. \& Farquhar, S. S. (2008) "Corporate Governance and Ethics: A Feminist Perspective". Journal of Business Ethics, 81, 665-678.

Marshall, R., Smith, M. \& Armstrong, R. (2014) Ethical Issues Facing Tax Professionals A Comparative Survey of Tax Agents and Practitioners in Australia. Asian Review of Accounting, 18 (3), 197-220.

Martinez, A. L. \& Lessa, R. C. (2014) The Effect of Tax Aggressiveness and Corporate Goverance on Audit Fees Evidences from Brazil, Journal of Management Research, $6(1), 95-108$. 
McGee, R. W. \&. Cohn, G. M. (2008) "Jewish Perspectives on the Ethics of Tax Evasion". Journal of Legal, Ethical and Regulatory Issues, 11 (2).

McDonald, J. L. (2010) "Are Tax and Non-Tax Factors Associated with FIN 48 Disclosures?" Dissertation form Texas A \& M University.

McNutt, P. A. (2010) "Guest Editorial Edited Ethics: Corporate Governance and Kant's Philosophy". International Journal of Social Economics, 37 (10), 741-754.

Meyer, R. A. (2003) "The Effects of Source Credibility on Tax Professional Judgment in Consulting Engagements". The Journal of the American Taxation Association: Supplement, 25 (1), 33-49.

Minnick, K. \& Noga, T. (2010) "Do Corporate Governance Characteristics Influence Tax Management?", Journal of Corporate Finance, 16, 703-718.

Moore, J. A. (2006). Do Board and Audit Committee Independence Affect Tax Reporting Aggressiveness? Dissertation from Arizona State University.

Mulfrod, C. W. \& Comiskey, E. E. (2002) The Financial Numbers Game - Detecting Creative Accounting Practices. Canada: John Wiley \& Son, Inc.

Musgrave, R. A. \& Musgrave, P. B. (1989) Public Finance in Theory and Practice. New York: McGraw-Hill.

Nachrowi, D. \& Usman, H. (2006) Pendekatan Populer dan Praktis Ekonometrika untuk Analisis Ekonomi dan Keuangan. Jakarta, Lembaga Penerbit FEUI.

Nienaber, S. G. (2010) "Factors That Could Influence The Ethical Behaviour of Tax Professionals". Meditari Accountancy Research, 18 (1), 33-46.

Nugroho, A. D. (2016, November 11) Masa Depan Transparansi Pajak. Kompas. http://print.kompas.com.

Tanpa Reformasi, Negara Kian Tekor BBM dan Pajak Jadi Sasaran. (2014, Agustus 15). Kompas.

Noor, R. Md., Fadzillah, N. S. M. \& Mastuki, N. (2010) "Corporate Tax Planning: A Study On Corporate Effective Tax Rates of Malaysian Listed Companies". International Journal of Trade, Economics and Finance, 1 (2), August, 189-193.

Nugent, D. A. (2013) "Legislating Moralty: The Effect of Tax Law Complexity on Taxpayers' Attitudes". The Journal of Applied Business Research, 29 (5), September/October, 1479-1494.

Obay, L. A. (2009) "Corporate Governance \& Business Ethics: A Dubai-Based Survey". Journal of Legal, Ethical and Regulatory Issues, 12 (2), 29-47.

O'Neil, C. J. \& Samelson, D. P. (2001) Behavioral research in taxation: Recent advances and future prospects, Advances in Accounting Behavioral Research, 4, Emerald Group Publishing Limited, 103 - 139.

Otman, Z. \& Rahman, R. A. (2010) "Ethics in Malaysian Corporate Governance Practices". International Journal of Business and Social Science, 1 (3), December, 98-109.

Palau, S. L. (2006) "Culture Effects in the Ethical Decision-making Process of Latin American Accountants". Dissertation from University of Texas-Pan American.

Paligorova, T. (2010) "Corporate Risk Taking and Ownership Structure, Bank of Canada" Working Paper, 3.

Pohan, H. T. (2008) "Analisis Pengaruh Kepemilikan Institusi, Rasio Tobin Q, Akrual Pilihan, Tarif Efektif Pajak, dan Biaya Pajak Ditunda Terhadap Penghindaran Pajak 
pada Perusahaan Publik". Jurnal Informasi, Perpajakan, Akuntansi dan Keuangan Publik, 4 (2), Juli, 113 - 135.

Pranata, F.M., Puspa, D.F. \& Herawati. (2013) "Pengaruh karakter eksekutif dan tata kelola terhadap tax avoidance". Jurnal Akuntansi Fakultas Ekonomi Universitas Bung Hatta.

Preuss, L. (2010) "Tax Avoidance and Corporate Social Responsibility: You Can't do Both, or Can You?" Corporate Governance, 1 (4), 365-374.

Purnamawati, St. V. \& Chrismastuti, A. A. (2006) "Dampak Reinforcement Contingency terhadap Hubungan Sifat Machiavellian dan Perkembangan Moral". Simposium Nasional Akuntansi IX. Padang.

Rego, S. O. \& Wilson, R. (2009) Executive Compensation, Tax Reporting Aggressiveness, and Future Firm Performance. https://www.researchgate.net. (diakses 2 Juli 2014).

Rego, S. O. \& Wilson, R. (2011) Equity Risk Incentives and Corporate Tax Aggressiveness. http://onlinelibrary.wiley.com. (diakses 24 Juni 2014).

Republik Indonesia. (2007) Undang-undang Nomor 28 tentang Ketentuan Umum Perpajakan.

Republik Indonesia. (2014) Peraturan Menteri Keuangan Nomor PMK-111/PMK-03/2014 tentang Konsultan Pajak.

Republik Indonesia. (2012) Surat Edaran Direktorat Jenderal Pajak Nomor SE-40/PJ/2012 tentang Pembuatan Benchmark Behavioral Model (BBM) dan Tindak Lanjutnya.

Richardson, G. (2006) "Determinants of Tax Evasion: A Cross-Country Investigation". Journal of International Accounting, Auditing and Taxation, 15 (2), 150-169.

Richmond, K. (2003) "Machiavellianism and Accounting: An Analysis of Ethical Behavior of US Undergraduate Accounting Student and Accountants". Symposium on Ethics Research in Accounting, American Accounting Association.

Ritter, D. E. \& Shampton, J. (2010) "Tax Planning: Avoiding The Rule Against Perpetuities with Foreign-based trusts - why, how and whether (ethically speaking)". Journal of Finance and Accountancy.

Rofiq, A. (2007) "Pengaruh Dimensi Kepercayaan (Trust) Terhadap Partisipasi Pelanggan E-Commerce". Jurnal Manajemen Fakultas Ekonomi Universitas Brawijaya.

Ross, A. M. \& McGee, R. W. (2012) "Attitudes Toward Tax Evasion : A Demographic Study of the Netherlands". Journal of International Business Research, 11, 2.

Ross, A. M. \& McGee, R. W. (2012) "Education Level and Ethical Attitude Toward Tax Evasion: A Six Country Study". Journal of Legal, Ethical and Regulatory Issues, 15, 2.

Rotimi, O., Aka Udu, U. S. \& Abdul-Azeez, A. A. (2013) "Revenue Generation and Engagement of Tax Consultant in Logos State, Nigeria: Continuous Tax Evasion and Irregularities". European Journal of Business and Social Sciences, 1 (10), 25-35.

Sabli, N. \& Noor, R. Md. (2012) "Tax Planning and Corporate Governance". $3^{\text {rd }}$ International Conference on Business and Economic. Bandung.

Schoorman, F. D., Mayer, R. C. \& Davis, J. H. (2007) "An Integrative Model of Organizational Trust: Past, Present and Future". Academy of Management Review, 32 (2), 344-354.

Scott, W. R. (2015) Financial Accounting Theory. Seventh Edition. Pearson Canada Toronto. 
Sekaran, U. \& Bougie, R. (2010) Research Methods for Business A Skill Building Approach. Fifth Edition. Wiley.

Sembel, R. (2016) Berpikir Ekonomis Di Masa Krisis Gagasan Akademis yang Wajib Diketahui oara Praktisi. KontanPublishing.

Shafer, W. E. \& Simmons, R. S. (2008) "Social responsibility, Machiavellianism and tax avoidance A study of Hong Kong tax professionals". Accounting, Auditing \& Accountability Journal, 21 (5), 695-720.

Shaw, K. W. (2012) CEO Incentives and The Cost of Debt. Rev. Quant Finan Acc, 38, 323-346.

Sholihin, M. \& Ratmono, D. (2013) Analisis SEM-PLS dengan WarpPLS 3.0. Penerbit Andi Yogyakarta.

Steijvers, T. \& Niskanen, M. (2007) Tax Aggressive Behaviour in Private Family Firms The Effect of the CEO and Board of Directors. https://doclib.uhasselt.be. (diakses 24 Juni 2014).

Stuebs, M. \& Wilkinson, B. (2010) Ethics and the Tax Profession: Restoring the Public Interest Focus. Accounting and the Public Interest, 10, 13-35.

Suandy, E. (2011) Perencanaan Pajak. Edisi 5. Jakarta, Salemba Empat.

Sugiyono. (2010) Metode Penelitian Bisnis. Cetakan Kelimabelas. Bandung: Alfabeta.

Suryadi. (2016) "Model Hubungan Kausal Kesadaran Pelayanan, Kepatuhan Pajak dan Pengaruhnya terhadap Kinerja Penerimaan Pajak". Jurnal Keuangan Publik. 4. 1.

Tajfel H., MG Billig, R. B. \& Flament, C. (1971) "Social Categorization and Intergroup Behavior". European Journal of Social Psychology, 1, 149-178.

Takril, N.F. \& Sanusi, S.W. (2011) “An exploratory study of malaysian tax practitioners' perception on the practice of aggressive tax avoidance". Kolej Universiti Islam Antarbangsa Selangor Journal. 218-231.

Tooma, R. (2006) Aggressive Tax Planning: When is aggressive too aggressive?, paper presented at the Tribeca 6th Annual Tax Planning Strategies Conference, Tribeca, Sydney, 22 March.

Torgler, B. (2003) Tax Morale: Theory and Empirical Analysis of Tax Compliance. Dissertation der Universitat Basel Zur Erlangung der Wurde eines Doktors der Staatswissenschaften.

Tuan, L. T. (2011) Corporate social responsibility, ethics, and corporate governnace. Social Responsibility Journal, 8 (4), 547-560.

Uppal J.S., (2005) Kasus Penghindaran Pajak Di Indonesia, Economic Review Journal, 201.

Velasquez, M. G. (2006) Business Ethics: Concepts and Cases. New Jersey: Pearson Prentice Hall.

Varelius, J. (2008) Ethics Consultation and Autonomy. Sci Eng Ethics, 14, 65-76.

Waegenaere, A. D., Sansing, R \& Wielhouwer, J. L. (2013) Financial accounting effects of tax aggressiveness: Contracting and measurement. http://ssrn.com. (diakses 3 September 2014).

Wahyuni, S. (2014) Hubungan Antara Kepercayaan Diri Dengan Kecemasan Berbicara di Depan Umum Pada Mahasiswa Psikologi. eJournal Psikologi, 2 (1), 50-64.

Winahyuningsih, P. (2010) Pengaruh Kepercayaan dan Kualitas Pelayanan Terhadap Kepuasan Konsumen Pada Hotel Griptha Kudus. http://www.umk.ac.id. (diakses 17 Nopember 2014). 
Waluyo, (2011) Perpajakan Indonesia. Edisi 10. Jakarta, Salemba Empat.

Wardani, E. S. (2009) "Pengaruh Kompensasi, Keahlian dan Motivasi Kerja Terhadap Prestasi Kerja Karyawan Pada PT. Pembangkitan Jawa Bali Unit Pembangkitan Muara Tawar". Jurnal Manajemen Universitas Gunadarma.

Wibowo. (2014) Perilaku dalam Organisasi. Edisi 1. Jakarta, Salemba Empat.

Widodo. (2009) Upaya Peningkatan Kinerja Sumber Daya Manusia Melalui Komitmen dan Orientasi Belajar. http: jurnal.ump.ac.id. (diakses 9 Nopember 2014).

Xynas, L. (2011) Tax Planning, Avoidance and Evasion in Australia 1970-2010: The Regulatory Responses and Taxpayer Compliance. Revenue Law Journal. 20.

Yuliana, \& Cahyonowati, N. (2012) "Analisis Pengaruh Persepsi Pentingnya Etika dan Tanggung Jawab Sosial, Sifat Machiavellian, dan Keputusan Etis Terhadap Niat Berpartisipasi dalam Penghindaran Pajak (Studi Empiris pada Konsultan Pajak di Semarang)". Diponegoro Journal of Accounting, 1, 1.

Yudkin, L. (1971) A Legal Structure for Effective Income Tax Administration - Tax Technique Handbook. International Tax Program, Harvard Law School.

Zain, M. (2008) Manajemen Perpajakan. Edisi Ketiga. Jakarta, Salemba Empat.

Zemzem, A. \& Ftouhi, K. (2013) "The Effects of Board of Directors' Characteristics on Tax Aggressiveness". Research Journal of Finance and Accounting, 4 (4), 140-147.

Zuber, J. M. (2007) Corporate Manager Aggressiveness in Tax Decision Making. Doctoral dissertation University of Arkansas. 